\title{
Synthesis of New 4-Methyl-2-(4-pyridyl)-1,2,3,4-tetrahydroquinolines as Potent Antifungal Compounds
}

\author{
Leonor Y. Vargas Méndez, ${ }^{a}$ Susana A. Zacchino ${ }^{b}$ and Vladimir V. Kouznetsov*,c \\ ${ }^{a}$ Grupo de Investigaciones Ambientales, Universidad Santo Tomas, A.A. 1076, Bucaramanga, Colombia \\ ${ }^{b}$ Laboratorio de Farmacognosia, Universidad Nacional del Rosario, Suipacha 531, Rosario, Argentina \\ ${ }^{c}$ Laboratorio de Química Orgánica y Biomolecular, Universidad Industrial de Santander, \\ A. A. 678, Bucaramanga, Colombia
}

\begin{abstract}
A síntese, a caracterização espectroscópica e os resultados biológicos de novas séries de 2-(4-piridil)-1,2,3,4-tetrahidroquinolinas e seus precursores, $-\mathrm{N}$-aril- $N$-[1-(4-piridil)but-3-enil] aminas, são descritos. Foi encontrado que ambos, precursores substituídos $\gamma$-piridil e os produtos finais, as tetrahidroquinolinas, demonstraram excelentes atividades antifúngicas contra Aspergillus fumigatus, Aspergillus flavus, Aspergillus niger, Microsporum gypseun, Trichophyton rubrum e Trichophyton mentagrophytes.
\end{abstract}

Synthesis, spectral characterization and biological results of new series of 2-(4-pyridyl)1,2,3,4-tetrahydroquinolines and their closer precursors, $-N$-aryl- $N$-[1-(4-pyridyl)but-3-enyl] amines are reported. It was found that both $\gamma$-pyridyl substituted precursors and final products, tetrahydroquinolines, showed very good antifungal activities against Aspergillus fumigatus, Aspergillus flavus, Aspergillus niger, Microsporum gypseun, Trichophyton rubrum and Trichophyton mentagrophytes.

Keywords: homoallylamines, 2-(4-pyridyl)-1,2,3,4-tetrahydroquinolines, antifungal activity

\section{Introduction}

Both alicyclic and cyclic secondary amines are widely used throughout the chemical industry as basic intermediates to prepare fine chemicals, pharmaceuticals and agrochemicals. ${ }^{1,2}$ Moreover, they are one of the most common structural features of naturally occurring biologically active compounds. Due to their unique biological properties, these compounds have played an important role in chemotherapeutic approaches to a variety of diseases, including fungal infectious diseases. These compounds serve as interesting pharmacological models in biomedicine studies. So, chemistry and biology of these compounds have received considerable attention from both the theoretical and practical points of view.

As a part of our ongoing drug discovery program we have been actively involved in determining the features that are important for antifungal activities of $N$-pyridylmethylanilines, and $N$-aryl- $N$-[1-(3-pyridyl) but-3-enyl]amines ("homoallylamines"), easily accessible from aldimines. Both type of compounds displayed significant activity ( $\mathrm{MIC}<50 \mu \mathrm{g} \mathrm{mL}^{-1}$ ) against some pathogenic dermatophytes. ${ }^{3-6}$ We found also that some 4-methyl-1,2,3,4-tetrahydroquinolines are active against yeasts, hialohyphomycetes as well as dermatophytes. A point of connection between homoallylamines and tetrahydroquinolines, apart from their similar type of bioactivity, is that the first ones are suitable precursors for the corresponding 2,4-substituted 1,2,3,4-tetrahydroquinolines via acid-promoted intramolecular 6-exo-trig cyclization, that was described in 1994 by our team. ${ }^{7,8}$ These facts encouraged us to develop other analogs of simple 4-methyltetrahydroquinoline derivatives with possible antifungal activity. Herein, we report the synthesis, spectral characterization and biological results of new series of 2-(4-pyridyl)-1,2,3,4-tetrahydroquinolines and their closer precursors, $-N$-aryl- $N$-[1-(4-pyridyl)but-3-enyl]amines that could be considered as interesting hits for antifungal drug development.

*e-mail: kouznet@uis.edu.co 


\section{Results and Discussion}

The series of homoallylamines 6-10 were prepared using both standard Grignard and Barbier procedures ${ }^{9}$ with prepared in situ allyl bromide magnesium in ether and with allyl bromide/indium/methanol system, respectively. Performing this later procedure, a mixture of allyl bromide ( $3 \mathrm{mmol})$, powder indio $(1.5 \mathrm{mmol})$ and aldimines $\mathbf{1 - 5}$ (1 mmol) in dry $\mathrm{MeOH}$ was stirred at room temperature until the complete dissolution of metal, taking 1-4 $\mathrm{h}$ to obtain the desired products. Classical Grignard protocol consists in the addition of an ether solution of aldimines to preformed allyl magnesium bromide in ether that affords desired amine products. Thus, this nucleophilic addition was realized in ether (or THF) at $20^{\circ} \mathrm{C}$ and, after stirring for $4 \mathrm{~h}$, the reaction mixture was treated with saturated $\mathrm{NH}_{4} \mathrm{Cl}$ solution. The organic products were extracted affording the homoallylamines 6-10 in 53-81\% yields (Scheme 1, Table 1). It is worth noting that the use of ether is limited by the solubility of utilized aldimines.

Each of these procedures demonstrated some advantages and disadvantages: traditional Grignard protocol needs to use commercial, expensive organometallic reagent and dry solvents that are toxic and expensive, but magnesium is an easily available and inexpensive metal. Barbier protocol does not need to form organometallic reagent and dry solvents, but indium is still a very expensive metal to perform scale-up preparation of precursor compounds.

Homoallylamines 6-10 were easily characterized by IR $\left(v_{\mathrm{NH}} 3273\right.$ and $\left.3293 \mathrm{~cm}^{-1}\right),{ }^{1} \mathrm{H}-\mathrm{NMR}$, and Mass Spectra.
This later technique demonstrated that molecular ions were of low intensity $(<5 \%)$ and the principal fragmentation of these compounds were due to the lost of allyl radical $[\mathrm{M}-41]^{+}$, that generates ArNHCHPy ${ }^{+}$-cations. ${ }^{10}{ }^{1} \mathrm{H}-\mathrm{NMR}$ spectra of homoallylamines 6-10 were very similar one each other, and were characterized by the presence of three groups of signals, which resonated in different zones (Table 2).

Preparation of desired 1,2,3,4-tetrahydroquinolines 11-14 consisted in the simple treatment of obtained homoallylamines mainly with sulfuric acid (85\%). This mixture was heated at $80-90{ }^{\circ} \mathrm{C}$ during $1-5 \mathrm{~h}$. Final products were isolated, and then purified by alumina column chromatography. In the case of homoallylamine 8, PPA was used as mild cycling agent, because its treatment with sulfuric acid gave a complex mixture of inseparable products. It should be also noted that during the sulfuric acid catalysis of homoallylamine 10, quinoline sulfonic acid $\mathbf{1 5}$ was formed as a sulfonation and oxidation product in considerable yields (Table 3 ). The structure of each final product was strongly confirmed by NMR $\left({ }^{1} \mathrm{H},{ }^{13} \mathrm{C}\right)$, IR and GC-MS data.

Analysing GC-MS and NMR data, it was noted that final products 11-14 presented a mixture of two diastereomers (cis and trans) from different spatial orientation of the substituents at C-2 and C-4 positions. GC-MS data indicated that the cis:trans ratio for comp. 11-14 were: 68:32; 79:21; 88:12 and 91:9, respectively. From NMR studies it was possible to assign cis-form for major isomer. This was corroborated by the protons $2-\mathrm{H}, 3-\mathrm{H}$ and $4-\mathrm{H}$ coupling
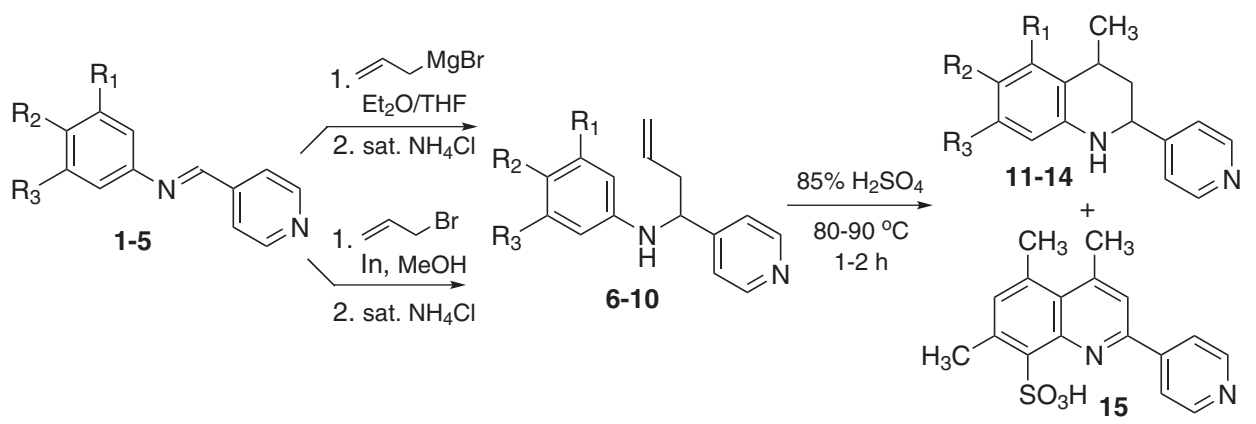

Scheme 1

Table 1. Physicochemical constants of homoallylamines 6-10

\begin{tabular}{|c|c|c|c|c|c|c|c|c|c|}
\hline \multirow{2}{*}{ Comp. } & \multirow{2}{*}{$\mathrm{R}_{1}$} & \multirow{2}{*}{$\mathrm{R}_{2}$} & \multirow{2}{*}{$\mathrm{R}_{3}$} & \multirow{2}{*}{$\begin{array}{l}\text { Molecular } \\
\text { formula }\end{array}$} & \multirow{2}{*}{$\mathrm{mp} /{ }^{\circ} \mathrm{C}$} & \multicolumn{2}{|c|}{ GC-MS } & \multicolumn{2}{|c|}{ Yield / \% ${ }^{\mathrm{a}}$} \\
\hline & & & & & & $\mathrm{t}_{\mathrm{R}} / \min$ & $\mathrm{M}^{++}, m / z(\mathrm{I}, \%)$ & Grignard protocol & Barbier protocol \\
\hline 6 & $\mathrm{H}$ & $\mathrm{H}$ & $\mathrm{H}$ & $\mathrm{C}_{15} \mathrm{H}_{16} \mathrm{~N}_{2}$ & oil & 17.27 & $224(3)$ & 81 & 62 \\
\hline 7 & $\mathrm{H}$ & $\mathrm{Me}$ & $\mathrm{H}$ & $\mathrm{C}_{16} \mathrm{H}_{18} \mathrm{~N}_{2}$ & $95-96$ & 19.27 & $238(4)$ & 73 & $\mathrm{nt}^{\mathrm{b}}$ \\
\hline 8 & $\mathrm{H}$ & $\mathrm{OMe}$ & $\mathrm{H}$ & $\mathrm{C}_{16} \mathrm{H}_{18} \mathrm{~N}_{2} \mathrm{O}$ & oil & 21.32 & $254(5)$ & 60 & $\mathrm{nt}^{\mathrm{b}}$ \\
\hline 9 & $\mathrm{H}$ & $\mathrm{Br}$ & $\mathrm{H}$ & $\mathrm{C}_{15} \mathrm{H}_{15} \mathrm{BrN}$ & $81-83$ & 22.15 & $302(5)$ & 53 & 53 \\
\hline 10 & $\mathrm{Me}$ & $\mathrm{H}$ & $\mathrm{Me}$ & $\mathrm{C}_{17} \mathrm{H}_{20} \mathrm{~N}_{2}$ & $91-92$ & 19.99 & $252(3)$ & 74 & 70 \\
\hline
\end{tabular}

aisolated yield. ${ }^{b}$ not tested. 
Table 2. ${ }^{1} \mathrm{H}$ MNR data of 4- $N$-aryl- $N$-[1-(4-pyridyl)buten-3-yl]amines 6-10

\begin{tabular}{|c|c|c|c|c|c|c|c|c|c|c|}
\hline \multirow{3}{*}{ Comp. } & \multicolumn{10}{|c|}{ Chemical shifts $(\delta /$ ppm, constants / Hz) } \\
\hline & \multicolumn{2}{|c|}{ Alkene part } & \multicolumn{3}{|c|}{ Other } & \multicolumn{2}{|c|}{ Py } & \multicolumn{2}{|c|}{ Aryl } & \multirow{2}{*}{$\mathrm{R}$} \\
\hline & $\mathrm{CH}_{2}=$ & $=\mathrm{CH}$ & $-\mathrm{CH}_{2}$ & $-\mathrm{CH}$ & $\mathrm{N}-\mathrm{H}$ & $2(6)-\mathrm{H}_{\mathrm{Py}}$ & $3(5)-\mathrm{H}_{\mathrm{Py}}$ & $2(6)-\mathrm{H}_{\mathrm{Ar}}$ & $3(5)-\mathrm{H}_{\mathrm{Ar}}$ & \\
\hline 6 & $\begin{array}{l}5.18-5.24 \\
\quad(\mathrm{~m})\end{array}$ & $\begin{array}{l}5.66-5.80 \\
(\mathrm{~m})\end{array}$ & $\begin{array}{l}2.43-2.66 \\
(\mathrm{~m})\end{array}$ & $\begin{array}{l}4.38(\mathrm{dd}) \\
J 7.9,5.0\end{array}$ & $\begin{array}{l}4.19 \\
\text { (bs) }\end{array}$ & $\begin{array}{l}8.56(\mathrm{dd}) \\
J 5.0,1.6\end{array}$ & $\begin{array}{l}7.31(\mathrm{dd}) \\
J 4.4,1.6\end{array}$ & $\begin{array}{c}6.45(\mathrm{~d}) \\
J 8.5\end{array}$ & $\begin{array}{l}7.10(\mathrm{td}) \\
J 7.7,1.0\end{array}$ & $\begin{array}{c}4-\mathrm{H}_{\mathrm{Ar}} \\
6.69(\mathrm{t}), J \quad J .3\end{array}$ \\
\hline 7 & $\begin{array}{c}5.18(\mathrm{~s}) \\
5.21(\mathrm{~d}) J 7.8\end{array}$ & $\begin{array}{l}5.68-5.78 \\
(\mathrm{~m})\end{array}$ & $\begin{array}{l}2.43-2.64 \\
(\mathrm{~m})\end{array}$ & $\begin{array}{l}4.34(\mathrm{dd}) \\
J 7.7,5.0\end{array}$ & $\begin{array}{l}4.09 \\
\text { (bs) }\end{array}$ & $\begin{array}{l}8.55(\mathrm{dd}) \\
J 4.6,1.4\end{array}$ & $\begin{array}{l}7.31(\mathrm{dd}) \\
J 4.7,1.1\end{array}$ & $\begin{array}{c}6.38(\mathrm{~d}) \\
J 8.4\end{array}$ & $\begin{array}{c}6.91(\mathrm{~d}) \\
J 8.0\end{array}$ & $\begin{array}{c}\mathrm{CH}_{3} \\
2.20(\mathrm{~s})\end{array}$ \\
\hline 8 & $\begin{array}{c}5.16(\mathrm{~s}) \\
5.20 \text { (d) J } 6.0\end{array}$ & $\begin{array}{l}5.67-5.77 \\
(\mathrm{~m})\end{array}$ & $\begin{array}{l}2.41-2.61 \\
(\mathrm{~m})\end{array}$ & $\begin{array}{l}4.29(\mathrm{dd}) \\
J 8.0,5.0\end{array}$ & - & $\begin{array}{l}8.53(\mathrm{dd}) \\
J 4.5,1.5\end{array}$ & $\begin{array}{c}7.29(\mathrm{~d}) \\
J 6.0\end{array}$ & $\begin{array}{c}6.40(\mathrm{~d}) \\
J 8.9\end{array}$ & $\begin{array}{c}6.68(\mathrm{~d}) \\
J 8.9\end{array}$ & $\begin{array}{l}\mathrm{OCH}_{3} \\
3.68(\mathrm{~s})\end{array}$ \\
\hline 9 & $\begin{array}{l}5.17-5.23 \\
(\mathrm{~m})\end{array}$ & $\begin{array}{l}5.63-5.78 \\
(\mathrm{~m})\end{array}$ & $\begin{array}{l}2.42-2.67 \\
(\mathrm{~m})\end{array}$ & $\begin{array}{l}4.34 \\
(\mathrm{~m})\end{array}$ & $\begin{array}{l}4.19 \\
(\mathrm{~s})\end{array}$ & $\begin{array}{l}8.55(\mathrm{dd}) \\
J 4.4,1.6\end{array}$ & $\begin{array}{l}7.27(\mathrm{dd}) \\
J 3.9,1.7\end{array}$ & $\begin{array}{l}6.31(\mathrm{dd}) \\
J 8.8,2.0\end{array}$ & $\begin{array}{l}7.16(\mathrm{dd}) \\
J 8.8,2.0\end{array}$ & - \\
\hline 10 & $\begin{array}{l}5.20-5.15 \\
\quad(\mathrm{~m})\end{array}$ & $\begin{array}{l}5.65-5.76 \\
(\mathrm{~m})\end{array}$ & $\begin{array}{l}2.41-2.62 \\
(\mathrm{~m})\end{array}$ & $\begin{array}{l}4.35(\mathrm{dd}) \\
J 7.7,5.0\end{array}$ & $\begin{array}{l}4.07 \\
(\mathrm{~s})\end{array}$ & $\begin{array}{l}8.54(\mathrm{dd}) \\
J 4.5,1.5\end{array}$ & $\begin{array}{l}7.29(\mathrm{dd}) \\
J 4.7,1.3\end{array}$ & $\begin{array}{l}6.08 \\
(\mathrm{~s})\end{array}$ & $\begin{array}{l}7.17(\mathrm{td}) \\
J 7.4,1.0\end{array}$ & $\begin{array}{c}3(5)-\mathrm{CH}_{3} 2.15(\mathrm{~s}) \\
4-\mathrm{H}_{\mathrm{Ar}} 6.34(\mathrm{~s})\end{array}$ \\
\hline
\end{tabular}

constants $\left(J_{\text {2ax,3ax }} 11.2-11.3 \mathrm{~Hz}, J_{2 \text { ax,3eq }} 2.3-2.9 \mathrm{~Hz}\right.$ and $J_{\text {4ax,3eq }}$ 6.0-6.9 Hz, and $J_{\text {4ax, 3ax }} 11.5-12.7 \mathrm{~Hz}$ ), affirmation enough to indicate the equatorial-equatorial (cis) relationship to the case (Table 4). Figure 1 shows both diastereomeric forms. All our attempts in the separation of these diastereomers by gravity column chromatography failed in our hands, only the major diastereomer of comp. $\mathbf{1 3}$ was isolated and characterized as a pure $c i s$-form.

The antifungal properties of compounds 6-14 were evaluated by the microbroth dilution method following the guidelines of the Clinical and Laboratory Standard Institute (CLSI, formerly National Committee for Clinical and Laboratory Standards (NCCLS) against a panel of ten fungal species: four human opportunistic pathogenic yeasts, three hialohyphomycetes and three dermatophytes. To carry out the antifungal evaluation, concentrations of compounds up to $250 \mu \mathrm{g} \mathrm{mL}^{-1}$ were incorporated to
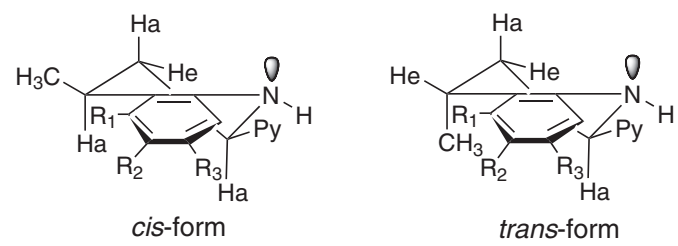

Figure 1. Spatial representation of cis-2eq,4eq and trans-2eq,4ax forms for the 2,4-disubstituted tetrahydroquinolines. growth media according to published procedures. ${ }^{11,12}$ The three most clinically used type of antifungal drugs were used as positive controls: the polyene Amphotericin B, the allylamine terbinafine and the azole ketoconazole. Biological results on fungal inhibition of the prepared molecules are summarized in Tables 5,6.

Regarding the activity displayed by homoallylamines 6-10 against the three most active fungal species, $M$. gypseum, T. rubrum and T. mentagrophytes, it appears that a substituent in the $p$-position produces an enhancement of the antifungal activity since 11 out the $12 \mathrm{MIC}$ values of compounds 7-9 are lower than the corresponding MICs of compound 6. In addition, the electronic properties of the $p$-substituents could play a role in the antifungal activity since compound 9 with a electron-withdrawing substituent (Br) was more active (MIC range $=16-31.2 \mu \mathrm{g} \mathrm{mL}^{-1}$ ) than compounds $\mathbf{7}$ and $\mathbf{8}$, which contain electron-donating groups $\left(\mathrm{CH}_{3}\right.$ and $\left.\mathrm{OCH}_{3}\right)$ and their MICs range were 25-125 $\mu \mathrm{g} \mathrm{mL}^{-1}$. Another interesting observation is that methyl groups in both, the positions C-3 and C-5, do not significantly modify the activity (compare the activity of 6 with 10).

Regarding tetrahydroquinolines, the high activity displayed by compound 11, clearly showed that the closing of the ring dramatically enhanced the activity of the

Table 3. Physicochemical parameters of THQ 11-14 and quinoline 15

\begin{tabular}{lccccccccc}
\hline Comp. & $\mathrm{R}_{1}$ & $\mathrm{R}_{2}$ & $\mathrm{R}_{3}$ & Molecular formula & $\mathrm{mp} /{ }^{\circ} \mathrm{C}$ & $\begin{array}{c}\mathrm{IR} \\
\left(\mathrm{v}_{\mathrm{NH}} / \mathrm{cm}^{-1}\right)\end{array}$ & $\begin{array}{c}\mathrm{GC}-\mathrm{MS} \\
\mathrm{t}_{\mathrm{R}} / \mathrm{min}\end{array}$ & $\begin{array}{c}\mathrm{M}^{+}, m / z \\
(\mathrm{I} / \%)\end{array}$ & $\begin{array}{c}\text { Yield } / \% \mathrm{o} \\
\mathbf{1}\end{array}$ \\
\hline $\mathbf{1 1}$ & $\mathrm{H}$ & $\mathrm{H}$ & $\mathrm{H}$ & $\mathrm{C}_{15} \mathrm{H}_{16} \mathrm{~N}_{2}$ & $88-90$ & 3266 & $20.06 / 20.29$ & $224(9) / 244(91)$ & 84 \\
$\mathbf{1 3}$ & $\mathrm{H}$ & $\mathrm{Me}$ & $\mathrm{H}$ & $\mathrm{C}_{16} \mathrm{H}_{18} \mathrm{~N}_{2}$ & $138-139$ & 3299 & $20.78 / 21.84$ & $238(10) / 238(100)$ & 72 \\
$\mathbf{1 4}$ & $\mathrm{H}$ & $\mathrm{OMe}$ & $\mathrm{H}$ & $\mathrm{C}_{16} \mathrm{H}_{18} \mathrm{~N}_{2} \mathrm{O}$ & $113-115$ & 3267 & 22.74 & $254(100)$ & 54 \\
$\mathbf{1 5}$ & $\mathrm{H}$ & $\mathrm{Br}$ & $\mathrm{H}$ & $\mathrm{C}_{15} \mathrm{H}_{15} \mathrm{BrN}_{2}$ & $104-106$ & 3256 & $23.30 / 24.05$ & $304(5) / 304(97)$ & 68 \\
\hline
\end{tabular}

aisolated yield. 
Table 4. ${ }^{1} \mathrm{H}$ MNR data of tetrahydroquinolines 11-14 and quinoline 15

\begin{tabular}{|c|c|c|c|c|c|c|c|c|c|c|c|c|c|}
\hline \multirow{3}{*}{ Comp. } & \multicolumn{12}{|c|}{ Chemical shifts $(\delta / p p m$, constants $/ \mathrm{Hz})$} & \multirow{3}{*}{$\mathrm{R}$} \\
\hline & \multicolumn{10}{|c|}{ Tetrahydroquinoline ring } & \multicolumn{2}{|c|}{ Py } & \\
\hline & 2-Hax & 3-Hax & $3-\mathrm{Heq}$ & 4-Hax & $4-\mathrm{CH}_{3}$ & $\mathrm{~N}-\mathrm{H}$ & $5-\mathrm{H}$ & $6-\mathrm{H}$ & $7-\mathrm{H}$ & $8-\mathrm{H}$ & $2(6)-\mathrm{H}_{\mathrm{Py}}$ & $3(5)-\mathrm{H}_{\mathrm{Py}}$ & \\
\hline 11 & $\begin{array}{c}4.47(\mathrm{dd}) \\
J 11.3,2.8\end{array}$ & $\begin{array}{c}1.70(\mathrm{q}) \\
J 12.7\end{array}$ & $\begin{array}{c}2.11 \text { (ddd) } \\
J 12.9 \\
4.3,3.0\end{array}$ & $\begin{array}{c}3.13(\mathrm{sp}) \\
J 6.0\end{array}$ & $\begin{array}{l}1.34(\mathrm{~d}) \\
J 6.8\end{array}$ & $4.00(\mathrm{~s})$ & $\begin{array}{c}7.18(\mathrm{~d}) \\
J 7.7\end{array}$ & $\begin{array}{l}6.74(\mathrm{td}) \\
J 7.4,0.9\end{array}$ & $\begin{array}{l}7.03(\mathrm{t}) \\
J 7.6\end{array}$ & $\begin{array}{l}6.56(\mathrm{dd}) \\
J 7.9,0.9\end{array}$ & $\begin{array}{l}7.35(\mathrm{dd}) \\
J 4.7,1.3\end{array}$ & $\begin{array}{l}8.58(\mathrm{dd}) \\
J 4.5,1.5\end{array}$ & - \\
\hline 12 & $\begin{array}{c}4.43(\mathrm{dd}) \\
J 11.3,2.6\end{array}$ & $\begin{array}{c}1.69(\mathrm{q}) \\
J 11.6\end{array}$ & $\begin{array}{c}2.10(\mathrm{ddd}) \\
J 12.9 \\
5.3,2.1\end{array}$ & $\begin{array}{c}3.12(\mathrm{sp}) \\
J 6.6\end{array}$ & $\begin{array}{l}1.34(\mathrm{~d}) \\
J 6.8\end{array}$ & $3.86(\mathrm{~s})$ & $7.00(\mathrm{~s})$ & - & $\begin{array}{c}6.86(\mathrm{~d}) \mathrm{J} \\
8.0\end{array}$ & $\begin{array}{c}6.50(\mathrm{~d}) \\
J 8.0\end{array}$ & $\begin{array}{l}7.35(\mathrm{dd}) \\
J 4.5,1.4\end{array}$ & $\begin{array}{l}8.58(\mathrm{dd}) \\
J 4.4,1.6\end{array}$ & $6-\mathrm{CH}_{3} 2.26(\mathrm{~s})$ \\
\hline 13 & $\begin{array}{l}4.40(\mathrm{dd}) \\
J 11.2,2.3\end{array}$ & $\begin{array}{c}1.69(\mathrm{q}) \\
J 11.6\end{array}$ & $\begin{array}{l}2.11(\mathrm{ddd}) \\
J 13.0 \\
5.5,2.7\end{array}$ & $\begin{array}{c}3.13(\mathrm{sp}) \\
J 6.3\end{array}$ & $\begin{array}{c}1.33(\mathrm{~d}) \\
J 6.8\end{array}$ & - & $\begin{array}{c}6.79(\mathrm{~d}) \\
J 2.7\end{array}$ & - & $\begin{array}{c}6.65(\mathrm{dd}) J \\
8.6,2.8\end{array}$ & $\begin{array}{l}6.56(\mathrm{~d}) \\
J 8.6\end{array}$ & $\begin{array}{l}7.36(\mathrm{dd}) \\
J 4.6,1.6\end{array}$ & $\begin{array}{l}8.58(\mathrm{dd}) \\
J 4.6,1.6\end{array}$ & $\mathrm{OCH}_{3} 3.76(\mathrm{~s})$ \\
\hline 14 & $\begin{array}{c}4.46(\mathrm{dd}) \\
J 11.2,2.9\end{array}$ & $\begin{array}{c}1.67(\mathrm{q}) \\
J 11.5\end{array}$ & $\begin{array}{c}2.09(\mathrm{bt}) \\
J 13.1\end{array}$ & $\begin{array}{c}3.10(\mathrm{sp}) \\
J 6.4\end{array}$ & $\begin{array}{c}1.33(\mathrm{~d}) \\
J 6.8\end{array}$ & 4.05 (bs) & $\begin{array}{l}7.27(\mathrm{~d}) \\
J 2.2\end{array}$ & - & $\begin{array}{c}7.11(\mathrm{dd}) \mathrm{J} \\
8.5,2.3\end{array}$ & $\begin{array}{l}6.45(\mathrm{~d}) \\
J 8.5\end{array}$ & $\begin{array}{l}7.34(\mathrm{dd}) \\
J 4.4,1.6\end{array}$ & $\begin{array}{l}8.59(\mathrm{dd}) \\
J 4.5,1.6\end{array}$ & - \\
\hline 15 & - & $7.59(\mathrm{~s})$ & & - & $2.75(\mathrm{~s})$ & & $7.17(\mathrm{~s})$ & - & - & - & $\begin{array}{l}8.69(\mathrm{dd}) \\
J 6.0,1.0\end{array}$ & $\begin{array}{l}7.93(\mathrm{dd}) \\
J 5.2,1.2\end{array}$ & $\begin{array}{c}5-\mathrm{CH}_{3} 2.39(\mathrm{~s}) ; \\
7-\mathrm{CH}_{3} 2.83(\mathrm{~s}), \\
\mathrm{O}-\mathrm{H} 9.17(\mathrm{bs})\end{array}$ \\
\hline
\end{tabular}

Table 5. Antifungal activity (MIC / $\mu \mathrm{g} \mathrm{mL} \mathrm{m}^{-1}$ ) of prepared molecules 6-14

\begin{tabular}{|c|c|c|c|c|c|c|c|c|c|c|}
\hline Comp. & $\mathrm{Ca}^{1}$ & $C t^{2}$ & $S c^{3}$ & $\mathrm{Cn}^{4}$ & $A f u^{5}$ & $A f t^{6}$ & $A n^{7}$ & $M g^{8}$ & $T r^{9}$ & $T m^{10}$ \\
\hline 6 & 250 & 250 & 125 & 250 & 250 & 250 & 250 & 125 & 250 & 62 \\
\hline 7 & $>250$ & 100 & 62 & 125 & 250 & 250 & $>250$ & 25 & 50 & 50 \\
\hline 8 & $>250$ & $>250$ & $>250$ & 250 & $>250$ & $>250$ & $>250$ & 62 & 125 & 125 \\
\hline 9 & $>250$ & $>250$ & 250 & $>250$ & $>250$ & $>250$ & $>250$ & 16 & 16 & 32 \\
\hline 10 & 250 & 250 & 250 & $>250$ & $>250$ & $>250$ & $>250$ & 125 & 250 & 125 \\
\hline 11 & 125 & 125 & 125 & 125 & 32 & 32 & 32 & 8 & 8 & 8 \\
\hline 12 & $>250$ & 100 & 100 & 25 & $>250$ & $>250$ & $>250$ & 25 & 50 & 25 \\
\hline 13 & 125 & 125 & 125 & 125 & 32 & 125 & 250 & 62 & 62 & 62 \\
\hline 14 & $>250$ & $>250$ & $>250$ & $>250$ & $>250$ & $>250$ & $>250$ & 125 & 125 & 125 \\
\hline Amp. & 1 & 0.5 & 0.5 & 0.25 & 0.5 & 0.5 & 0.5 & - & - & - \\
\hline Ket. & 0.5 & 0.12 & 0.5 & 0.25 & 0.12 & 0.5 & 0.25 & 0.05 & 0.025 & 0.025 \\
\hline Terb. & - & - & - & - & - & - & - & 0.04 & 0.01 & 0.04 \\
\hline
\end{tabular}

${ }^{1}$ Candida albicans ATCC 10231; ${ }^{2}$ Candida tropicalis C $131 ;{ }^{3}$ Saccharomyces cerevisiae ATCC $9763 ;{ }^{4}$ Cryptococcus neoformans ATCC $32264 ;{ }^{5}$ Aspergillus fumigatus ATCC 26934; ${ }^{6}$ Aspergillus flavus ATCC 9170; ${ }^{7}$ Aspergillus niger ATCC 9029; ${ }^{8}$ Microsporum gypseum C $115 ;{ }^{9}$ Trichophyton rubrum C 110 ; ${ }^{10}$ Trichophyton mentagrophytes ATCC 9972. Amp: Amphotericin B; Ket.: Ketoconazole; Terb.: Terbinafine.

unsubstituted homoallylamine 6, although the same was not observed for substituted homoallylamines 7-9. Compound 11 showed a broad spectrum of action inhibiting all fungi tested with MICs between 8 and $125 \mu \mathrm{g} \mathrm{mL}^{-1}$. It was highly active against Aspergillus spp. (MIC $\left.=31.2 \mu \mathrm{g} \mathrm{mL}^{-1}\right)$ and mainly against dermatophytes ( $\mathrm{MIC}=8 \mu \mathrm{g} \mathrm{mL^{-1 }}$ ).

The fact that tetrahydroquinoline molecule 11 inhibited Aspergillus spp. is highly interesting since it is worthwhile to take in account that previous homoallylamine-derived tetrahydroquinolines did not show activity against Aspergillus species up to $50 \mu \mathrm{g} \mathrm{mL}^{-1}$. $^{3,4}$

It is well known ${ }^{13}$ that invasive aspergillosis has emerged as a leading cause of infection-related mortality among immunocompromised individuals, in particular among recipients of hematopoietic stem cell transplants or solid organ transplants. Historically, the drug of choice for the treatment of invasive aspergillosis has been amphotericin $\mathrm{B}$, followed by the newer medications voriconazole and the recently approved caspofungin, which appeared more effective and with fewer side effects than the polyene. However, although the last drugs have advanced the management of these fungal infections, failure rates remain high, and emergence of intrinsically resistant fungi is a growing problem. ${ }^{14}$ So, there is a general consensus that the discovery of new structures acting against Aspergillus spp. is highly necessary. 
Regarding the activity of compounds $\mathbf{9}$ and $\mathbf{1 1}$ against dermatophytes, the most important findings are that these compounds display low MICs (16-32 and $8 \mu \mathrm{g} \mathrm{mL}^{-1}$, respectively) against both, T. rubrum and T. mentagrophytes. It is worthwhile to take in account that approximately $80-93 \%$ of chronic and recurrent dermatophyte infections (tineas) are estimated to be caused by Trichophyton spp. ${ }^{15}$ Although the treatment outcomes of these infections have now been greatly improved with the azole itraconazole or the allylamine terbinafine, there is unfortunately a considerable overlap of the strategies for treating the different tineas. This lack of specificity leads to chronic dermatophytoses or early re-infections after antifungal therapy and therefore, the superficial infections are very difficult to eradicate. ${ }^{15}$

The very low MIC displayed by compounds 9 and 11 against both Trichophyton spp. opens the possibility of using them as starting points for the development of new antifungal agents that selectively inhibit the most prevalent fungi in dermatomycoses. This hope is higher considering that both compounds not only inhibit but kill Trichophyton spp. (Minimum Fungicidal Concentration $=62 \mu \mathrm{g} \mathrm{mL} \mathrm{mL}^{-1}$ for compound 9 and 32-62 $\mu \mathrm{g} \mathrm{mL}^{-1}$ for compound 11) (Table 6) adding one of the needed requirements for being good candidates for future development.

Table 6. MIC-100 and MFC ( $\mu \mathrm{g} \mathrm{mL}-1)$ of compounds $\mathbf{9}$ and $\mathbf{1 1}$ against M. gypseum, T. rubrum y T. mentagrophytes

\begin{tabular}{lccc}
\hline & \multicolumn{3}{c}{ Activity / $\left(\mu \mathrm{g} \mathrm{mL}^{-1}\right)$} \\
\cline { 2 - 4 } Comp. & $\mathrm{Mg}^{1}$ & $\mathrm{Tr}^{2}$ & $\mathrm{Tm}^{3}$ \\
& $\mathrm{MIC}_{100} / \mathrm{MFC}$ & $\mathrm{MIC}_{100} / \mathrm{MFC}$ & $\mathrm{MIC}_{100} / \mathrm{MFC}$ \\
\hline $\mathbf{9}$ & $16 / 32$ & $16 / 62$ & $32 / 62$ \\
$\mathbf{1 1}$ & $8 / 16$ & $8 / 32$ & $8 / 62$ \\
\hline${ }^{1}$ Microsporum gypseum $\mathrm{C}$ & $115 ;{ }^{2}$ Trichophyton rubrum $\mathrm{C} 110 ;$ \\
${ }^{3}$ Trichophyton mentagrophytes ATCC 9972.
\end{tabular}

In summary, we found that both $\gamma$-pyridyl substituted precursors, homoallylamines, and final products, tetrahydroquinolines, showed very good antifungal activities against A. fumigatus, A. flavus, A. niger and the dermatophytes $M$. gypseum, T. rubrum and $T$. mentagrophytes. Among the compounds tested, the homoallylamine 9 and the tetrahydroquinoline $\mathbf{1 1}$ displayed the best activities against dermatophytes. Compound $\mathbf{1 1}$ showed also a very good activity against Aspergillus spp. In addition, $\mathbf{9}$ and $\mathbf{1 1}$ showed to be fungicide rather than fungistatic against dermatophytes, results that permit to consider them as good candidates for the further development of new antifungal agents.

\section{Experimental}

The melting points (uncorrected) were determined on a Fisher-Johns melting point apparatus. The IR spectra were recorded on a Lumex Infralum FT-02 spectrophotometer in $\mathrm{KBr} .{ }^{1} \mathrm{H}$ NMR spectra were recorded on Bruker AM400 spectrometer. Chemical shifts are reported in ppm $(\delta)$ relative to the solvent peak $\left(\mathrm{CHCl}_{3}\right.$ in $\mathrm{CDCl}_{3}$ at $7.24 \mathrm{ppm}$ for protons). Signals are designated as follows: s, singlet; $d$, doublet; dd, doublet of doublets; ddd, doublet of doublets of doublets; t, triplet; td, triplet of doublets; q, quartet; sp, septet; m, multiplet; b, broad. On DEPT-135 spectra, the signals of $\mathrm{CH}_{3}, \mathrm{CH}_{2}$ and $\mathrm{CH}$ carbons are shown as positive (+) and negative (-), respectively. Quaternary carbons are not shown. A Hewlett Packard 5890a series II Gas Chromatograph interfaced to an HP 5972 Mass Selective Detector (MSD) with an HP MS Chemstation Data system was used for ms identification at $70 \mathrm{EV}$ using a 60 m capillary column coated with HP-5 [5\%-phenylpoly(dimethyl-siloxane)]. Elemental analyses were performed on a Perkin Elmer 2400 Series II analyzer and were within \pm 0.4 of theoretical values. The reaction progress was monitored using thin layer chromatography on a silufol UV254 TLC aluminum sheet.

General procedure for the preparation of 4-N-aryl-N-[1(4-pyridyl)buten-3-yl]amines

\section{Grignard protocol}

To an $\mathrm{Et}_{2} \mathrm{O}$ solution $(200 \mathrm{~mL})$ of allyl magnesium bromide, prepared from allyl bromide $(36.3 \mathrm{~g}, 0.30 \mathrm{~mol})$ and magnesium (12.15 g, $0.50 \mathrm{~mol})$, were added slowly aldimines 1-5 $(0.10 \mathrm{~mol})$, dissolved in absolute THF $(50 \mathrm{~mL})$. The mixture was kept during $4 \mathrm{~h}$ at room temperature, and then cooled to $0{ }^{\circ} \mathrm{C}$ to treat rapidly with water, and finally with saturated ammonium chloride solution. The organic layer was separated and the aqueous layer was extracted with ether $(4 \times 50 \mathrm{~mL})$. The combined organic extracts were dried $\left(\mathrm{Na}_{2} \mathrm{SO}_{4}\right)$ and concentrated. The residue was purified by $\mathrm{Al}_{2} \mathrm{O}_{3}$ column chromatography (eluent - hexanes/ ethyl acetate) to give new homoallylamines 6-10, those physicochemical characteristics are shown in Tables 1,2.

\section{Barbier protocol}

To a mixture of aldimines $\mathbf{1}, \mathbf{4}$ and $\mathbf{5}(1 \mathrm{mmol})$ and powder indium $(170 \mathrm{mg}, 1.5 \mathrm{mmol})$ in methanol $(10 \mathrm{~mL})$ was added allyl bromide ( $365 \mathrm{mg}, 3 \mathrm{mmol}$ ). The reaction mixture was stirred vigorously at room temperature until all the indium had dissolved ( $1 \mathrm{~h}$ to $4 \mathrm{~h}$ ), at which time TLC indicated complete reaction. The reaction mixture was diluted with sat. $\mathrm{NH}_{4} \mathrm{Cl}$ solution and extracted with 
ethyl acetate. The extract was washed with brine and dried $\left(\mathrm{Na}_{2} \mathrm{SO}_{4}\right)$. The product was purified by flash column chromatography on alumina, using hexanes/ethyl acetate as eluent. Physicochemical characteristics of the obtained homoallylamines 6,9 and 10 were in agreement with those obtained by Grignard method.

General procedure for the preparation of 4-methyl-2(4-pyridyl)-1,2,3,4-tetrahydroquinolines

$85 \%$ (v/v) sulfuric acid $(4.0 \mathrm{~mL})$ was added dropwise at $0{ }^{\circ} \mathrm{C}$ to the homoallylamines 6-10 $(2.0 \mathrm{~g})$ in minimal $\mathrm{CH}_{2} \mathrm{Cl}_{2}$ amount, and the resulting mixture was heated at $80-90^{\circ} \mathrm{C}$ for $3 \mathrm{~h}$ while stirring vigorously. The reaction progress was monitored via TLC. At the end of the reaction the mixture was cooled down to room temperature and concentrated ammonium hydroxide solution was added to $\mathrm{pH} 10$. Four $25 \mathrm{~mL}$ extractions with dichloromethane were performed. The organic layers were combined, dried $\left(\mathrm{Na}_{2} \mathrm{SO}_{4}\right)$ and concentrated. The oily residue was purified by column chromatography over alumina to give new THQ 11-14 and quinoline sulfonic acid $\mathbf{1 5}$. The synthesis of THQ $\mathbf{1 3}$ was realized using PPA. Physicochemical characteristics of the obtained compounds are given in Table 3 .

\section{Antifungal evaluation}

\section{Microorganisms and media}

For the antifungal evaluation, standardized strains from the American Type Culture Collection (ATCC), Rockville, MD, USA, and CEREMIC (C), Centro de Referencia en Micología, Facultad de Ciencias Bioquímicas y Farmacéuticas, Suipacha 531-(2000)-Rosario, Argentina were used: Candida albicans ATCC 10231, Saccharomyces cerevisiae ATCC 9763, Cryptococcus neoformans ATCC 32264, Aspergillus flavus ATCC 9170, A. fumigatus ATTC 26934, A. niger ATCC 9029, Trichophyton rubrum C 110, T. mentagrophytes ATCC 9972, and M. gypseum C 115.

Strains were grown on Sabouraud-chloramphenicol agar slants for $48 \mathrm{~h}$ at $30^{\circ} \mathrm{C}$, maintained on slopes of Sabourauddextrose agar (SDA, Oxoid) and subcultured every 15 days to prevent pleomorphic transformations. Inocula of cell or spore suspensions were obtained according to reported procedures and adjusted to $1-5 \times 10^{3}$ cells/spores with colony forming units $(\mathrm{CFU}) \mathrm{mL}^{-1}$. 11,12

\section{Antifungal susceptibility testing}

Minimal Inhibitory Concentration (MIC) of each compound was determined by using broth microdilution techniques according to the guideliness of the CLSI (formerly NCCLS) M27-A2 ${ }^{11}$ and for filamentous fungi
M 38 A. ${ }^{12}$ MIC values were determined in RPMI-1640 (Sigma, St Louis, Mo, USA) buffered to $\mathrm{pH} 7.0$ with MOPS. Microtiter trays were incubated at $35^{\circ} \mathrm{C}$ for yeasts and hialohyphomycetes and at $28-30^{\circ} \mathrm{C}$ for dermatophyte strains in a moist, dark chamber, and MICs were visually recorded at $48 \mathrm{~h}$ for yeasts, and at a time according to the control fungus growth, for the rest of fungi.

Endpoints were defined as the lowest concentration of compound resulting in total inhibition $\left(\mathrm{MIC}_{100}\right.$ ) of visual growth compared to the growth control wells which contain culture medium and fungal inoculum but no antifungal drug.

For the assay, stock solutions of pure compounds were two-fold diluted with RPMI from 250-0.95 $\mu \mathrm{g} \mathrm{mL}^{-1}$ (final volume $=100 \mu \mathrm{L}$ ) and a final DMSO concentration $\leq 1 \%$. A volume of $100 \mu \mathrm{L}$ of inoculum suspension was added to each well with the exception of the sterility control where sterile water was added to the well instead. Ketoconazole (Sigma Chem. Co.), Terbinafine (Novartis, Bs. As.) and Amphotericin B (Sigma Chem. Co.) were used as positive controls. All tests were made by duplicate.

The minimum fungicidal concentration (MFC) of each compound against each strain was determined as follows: After determining the MIC, an aliquot of $5 \mu \mathrm{L}$ was withdrawn from each clear well of the microtiter tray and plated onto a 150-mm RPMI-1640 agar plate buffered with MOPS (Remel, Lenexa, Kans.). Inoculated plates were incubated at $30^{\circ} \mathrm{C}$, and MFC was recorded after $48 \mathrm{~h}$. The MFC was defined as the lowest concentration of each compound that resulted in total inhibition of visible growth in the agarized plate.

\section{Acknowledgments}

LYVM thanks COLCIENCIAS for her fellowship. VK thanks Instituto Colombiano para el Desarrollo de la Ciencia y la Tecnología "Francisco José de Caldas" (COLCIENCIAS-CENIVAM, contract No. 432-2004) and DIEF-UIS (grant No. 5151). SAZ thanks Agencia de Promoción Científica y Tecnológica de Argentina (ANPCyT), grant PICT 995 and RIBIOFAR (CYTED).

\section{Supplementary Information}

Supplementary data are available free of charge at http://jbcs.sbq.org.br, as PDF file.

\section{References}

1. Kleemann, A.; Engel, J.; Pharmaceutical Substances, Thieme: New York, 1999. 
2. Kuznetsov, V. V.; Andreeva, E. I.; Prostakov, N. S.; Khim. Farm. Zh. 1995, 29, 61. (CA, 1996, 124:48.290a).

3. Urbina, J. M. G.; Cortés, J. C.; Palma, A.; López, S. N.; Zacchino, S. A.; Enriz, D. R.; Ribas, J. C.; Kouznetsov, V.; Bioorg. Med. Chem. 2000, 8, 691.

4. Vargas Méndez, L. Y.; Castelli, M. V.; Kouznetsov, V. V.; Urbina, G. J. M.; López, S. N.; Sortino, M.; Enriz, R. D.; Ribas, J. C.; Zacchino, S. A.; Bioorg. Med. Chem. 2003, 11, 155.

Suvire, D. F.; Sortino, M.; Kouznetsov, V. V.; Vargas Méndez, L. Y.; Zacchino, S. A.; Mora Cruz, U.; Enriz, R. D.; Bioorg. Med. Chem. 2006, 14, 1851.

6. Kouznetsov, V. V.; Vargas Méndez, L. Y.; Sortino, M.; Vásquez, Y.; Gupta, M. P.; Freile, M.; Enriz, R. D.; Zacchino, S. A.; Bioorg. Med. Chem. 2008, 16, 794.

7. Vargas Méndez, L.Y.; Kouznetsov, V.; Heterocycl. Commun. 2002, 8, 583.

8. Vargas Méndez, L. Y.; Kouznetsov, V.; Stashenko, E.; Bahsas, A.; Amaro-Luis, J.; Heterocycl. Commun. 2001, 7, 323.

9. Kouznetsov, V. V.; Vargas Méndez, L. Y.; Synthesis 2008, 491.

10. Mikaya, A. I.; Lantsetov, S. V.; Kuznetsov, V. V.; Varlamov, A. V.; Prostakov, N. S.; Org. Mass Spectrom. 1991, 26, 763.
11. Clinical and Laboratory Standards Institute (CLSI, formerly National Committee for Clinical and Laboratory Standards NCCLS); Method M27-A2, $2^{\text {nd }}$ ed, Wayne, ed.; NCCLS: Pennsylvania, 2002, Vol. 22 (15), pp. 1-29.

12. Clinical and Laboratory Standards Institute (CLSI, formerly National Committee for Clinical and Laboratory Standards NCCLS); Method M-38A, $2^{\text {nd }}$ ed, Wayne, ed.; NCCLS: Pennsylvania, 2002, Vol. 22 (16), pp. 1-27.

13. Morgan, J.; Wannemuehler, K.; Marr, K.; Hadley, S.; Kontoyiannis, D.; Walsh, T.; Fridkin, S.; Pappas, P.; Warnock, D.; Med. Mycol. Suppl. 2005, 43, s49.

14. Maertens, J.; Raad, I.; Petrikkos, G.; Boogaerts, M.; Selleslag, D.; Petersen, F.; Sable, C.; Kartsonis, N.; Ngai, A.; Taylor, A.; Patterson, T.; Denning, D.; Walsh, T.J.; Clin. Infectious Diseases 2004, 39, 1563.

15. Weitzman, I.; Summerbell, R.; Clin. Microbiol. Rev. 1995, 8, 240.

16. Ablordeppey, S.; Fan, P.; Ablordeppey, J.; Mardenborough, L.; Curr. Med. Chem. 1999, 6, 1151.

Received: April 21, 2009

Web Release Date: October 20, 2009 


\title{
Synthesis of New 4-Methyl-2-(4-pyridyl)-1,2,3,4-tetrahydroquinolines as Potent Antifungal Compounds
}

\author{
Leonor Y. Vargas Méndez, ${ }^{a}$ Susana A. Zacchino ${ }^{b}$ and Vladimir V. Kouznetsov*,c \\ ${ }^{a}$ Grupo de Investigaciones Ambientales, Universidad Santo Tomas, A.A. 1076, Bucaramanga, Colombia \\ ${ }^{b}$ Laboratorio de Farmacognosia, Universidad Nacional del Rosario, Suipacha 531, Rosario, Argentina \\ ${ }^{c}$ Laboratorio de Química Orgánica y Biomolecular, Universidad Industrial de Santander, \\ A. A. 678, Bucaramanga, Colombia
}

\section{Experimental}

The melting points (uncorrected) were determined on a Fisher-Johns melting point apparatus. The IR spectra were recorded on a Lumex Infralum FT-02 spectrophotometer in $\mathrm{KBr} .{ }^{1} \mathrm{H}$ NMR spectra were recorded on Bruker AM400 spectrometer. Chemical shifts are reported in ppm $(\delta)$ relative to the solvent peak $\left(\mathrm{CHCl}_{3}\right.$ in $\mathrm{CDCl}_{3}$ at 7.24 ppm for protons). Signals are designated as follows: s, singlet; d, doublet; dd, doublet of doublets; ddd, doublet of doublets of doublets; t, triplet; dt, doublet of triplets; $\mathrm{td}$, triplet of doublets; q, quartet; quint., quintet; sext., sextet; m, multiplet; br, broad. On DEPT-135 spectra, the signals of $\mathrm{CH}_{3}, \mathrm{CH}_{2}$ and $\mathrm{CH}$ carbons are shown as positive (+) and negative (-), respectively. Quaternary carbons are not shown. A Hewlett Packard 5890a series II Gas Chromatograph interfaced to an HP 5972 Mass Selective Detector (MSD) with an hp ms Chemstation Data system was used for ms identification at $70 \mathrm{EV}$ using a $60 \mathrm{~m}$ capillary column coated with HP-5 [5\%-phenylpoly(dimethyl-siloxane)]. Elemental analyses were performed on a Perkin Elmer 2400 Series II analyzer and were within \pm 0.4 of theoretical values. The reaction progress was monitored using thin layer chromatography on a silufol UV254 TLC aluminum sheet.

General procedure for the preparation of 4- $\mathrm{N}$-aryl- $\mathrm{N}-[1-$ (4-pyridyl)buten-3-yl]amines

\section{Grignard protocol}

To an $\mathrm{Et}_{2} \mathrm{O}$ solution $(200 \mathrm{~mL})$ of allyl magnesium bromide, prepared from allyl bromide $(36.3 \mathrm{~g}, 0.30 \mathrm{~mol})$ and magnesium $(12.15 \mathrm{~g}, 0.50 \mathrm{~mol})$, were added slowly aldimines 1-5 $(0.10 \mathrm{~mol})$, dissolved in absolute THF

\footnotetext{
*e-mail: kouznet@uis.edu.co
}

$(15 \mathrm{~mL})$. The mixture was kept during $4 \mathrm{~h}$ at room temperature, and then cooled to $0{ }^{\circ} \mathrm{C}$ to treat rapidly with water, and finally with saturated ammonium chloride solution. The organic layer was separated and the aqueous layer was extracted with ether $(4 \times 50 \mathrm{~mL})$. The combined organic extracts were dried $\left(\mathrm{Na}_{2} \mathrm{SO}_{4}\right)$ and concentrated. The residue was purified by $\mathrm{Al}_{2} \mathrm{O}_{3}$ column chromatography (eluent - hexanes/ethyl acetate) to give new homoallylamines 6-10.

\section{Barbier protocol}

To a mixture of aldimines $\mathbf{1}, \mathbf{4}$ and $\mathbf{5}(1 \mathrm{mmol})$ and powder indium $(170 \mathrm{mg}, 1.5 \mathrm{mmol})$ in methanol $(10 \mathrm{~mL})$ was added allyl bromide $(365 \mathrm{mg}, 3 \mathrm{mmol})$. The reaction mixture was stirred vigorously at room temperature until all the indium had dissolved ( $1 \mathrm{~h}$ to $4 \mathrm{~h}$ ), at which time TLC indicated complete reaction. The reaction mixture was diluted with sat. $\mathrm{NH}_{4} \mathrm{Cl}$ and extracted with ethyl acetate. The extract was washed with brine and dried $\left(\mathrm{Na}_{2} \mathrm{SO}_{4}\right)$. The product was purified by flash column chromatography on alumina, using hexanes/ethyl acetate as eluent. Physicochemical characteristics of the obtained homoallylamines $\mathbf{6 , 9}$ and $\mathbf{1 0}$ were in agreement with those obtained by Grignard method.

\section{4-N-Phenyl-N-[1-(4-pyridyl)buten-3-yl]amine 6}

Yellow viscous oil. Yield: $81 \%$. Molecular formula: $\mathrm{C}_{15} \mathrm{H}_{16} \mathrm{~N}_{2}$. Molecular weight: $224.30 \mathrm{~g} \mathrm{~mol}^{-1}$. Eluent: petroleum eter/AcOEt, 10:1. IR $(\mathrm{KBr}) v_{\max } / \mathrm{cm}^{-1}: 3287$ $\left(v_{\mathrm{NH}}\right), 1601\left(v_{\mathrm{C}=\mathrm{CH}}\right) .{ }^{1} \mathrm{H}-\mathrm{NMR}\left(\mathrm{CDCl}_{3}, 400 \mathrm{MHz}\right) \delta(\mathrm{ppm})$ : 2.43-2.66 (2H, m, $\left.-\mathrm{CH}_{2}\right), 4.19(1 \mathrm{H}, \mathrm{bs}, \mathrm{N}-\mathrm{H}), 4.38(1 \mathrm{H}, \mathrm{dd}$, $J$ 7.9, $5.0 \mathrm{~Hz},-\mathrm{CH}), 5.18-5.24\left(2 \mathrm{H}, \mathrm{m},=\mathrm{CH}_{2}\right), 5.66-5.80$ $(1 \mathrm{H}, \mathrm{m},=\mathrm{CH}), 6.45\left(2 \mathrm{H}, \mathrm{d}, J 8.5 \mathrm{~Hz}, 2(6)-\mathrm{H}_{\mathrm{Ph}}\right), 6.69(1 \mathrm{H}$, tt, J 7.3 Hz, 4- $\left.\mathrm{H}_{\mathrm{Ph}}\right), 7.10\left(2 \mathrm{H}, \mathrm{td}, J 7.7,1.0 \mathrm{~Hz}, 3(5)-\mathrm{H}_{\mathrm{Ph}}\right)$, $7.31\left(2 \mathrm{H}, \mathrm{dd}, J 4.4,1.6 \mathrm{~Hz}, 3(5)-\mathrm{H}_{\mathrm{Py}}\right), 8.56(2 \mathrm{H}, \mathrm{dd}, J 5.0$, $\left.1.6 \mathrm{~Hz}, 2(6)-\mathrm{H}_{\mathrm{Py}}\right) \cdot{ }^{13} \mathrm{C}-\mathrm{NMR}$ (100 MHz) $\delta$ (ppm): 42.4, 


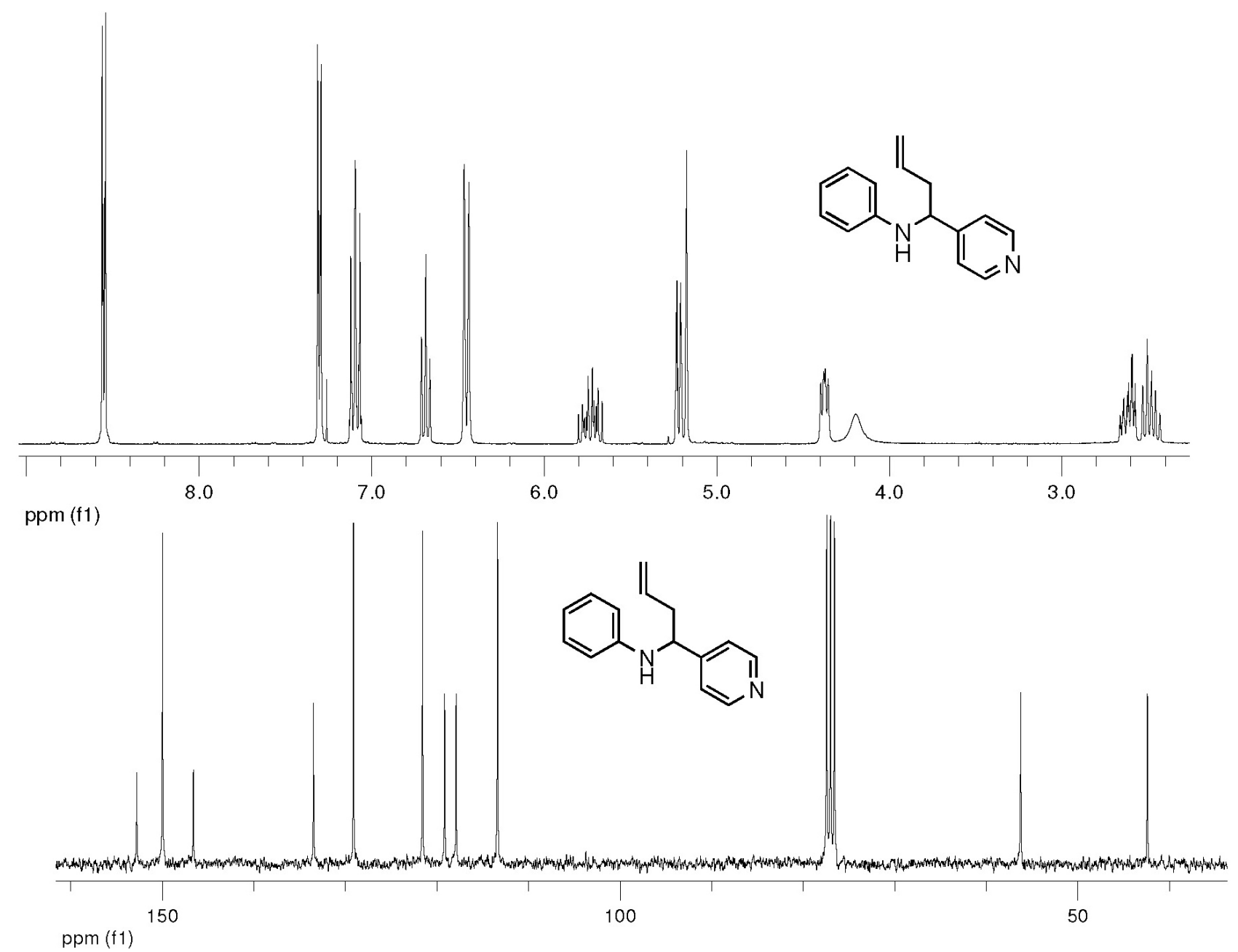

Figure S1. ${ }^{1} \mathrm{H}$ and ${ }^{13} \mathrm{C}$ NMR spectra of 6 .

56.2, 113.4 (2C), 117.9, 119.1, 121.6 (2C), 129.1 (2C), 146.6, 133.5, $150.0(2 \mathrm{C}), 152.8$. GC: $t_{\mathrm{R}} 17.27 \mathrm{~min}$. MS: $\mathrm{m} / \mathrm{z}(\%): 224\left(\mathrm{M}^{+}, 3\right), 183$ (100), 77 (11), 51 (4). Anal. calc. for $\mathrm{C}_{15} \mathrm{H}_{16} \mathrm{~N}_{2}: \mathrm{C}, 80.32 ; \mathrm{H}, 7.19 ; \mathrm{N}, 12.49$. Found: C, $80.54 ; \mathrm{H}, 7.04 ; \mathrm{N}, 12.40$.

4-N-(4-Methylphenyl)-N-[1-(4-pyridyl)buten-3-yl]amine 7

White crystals. mp $95-96{ }^{\circ} \mathrm{C}$. Yield: $73 \%$. Molecular formula: $\mathrm{C}_{16} \mathrm{H}_{18} \mathrm{~N}_{2}$. Molecular weight: $238.33 \mathrm{~g} \mathrm{~mol}^{-1}$. Eluent: petroleum eter/AcOEt, 20:1. IR (KBr) $v_{\max } / \mathrm{cm}^{-1}$ : $3273\left(v_{\mathrm{NH}}\right), 1599\left(v_{\mathrm{C}=\mathrm{CH}}\right) .{ }^{1} \mathrm{H}-\mathrm{NMR}\left(\mathrm{CDCl}_{3}, 400 \mathrm{MHz}\right) \delta$ (ppm): $2.20\left(3 \mathrm{H}, \mathrm{s}, \mathrm{CH}_{3}\right), 2.43-2.64\left(2 \mathrm{H}, \mathrm{m},-\mathrm{CH}_{2}\right), 4.09$ $(1 \mathrm{H}$, br. s, N-H), $4.34(1 \mathrm{H}, \mathrm{dd}, J 7.7,5.0 \mathrm{~Hz},-\mathrm{CH}), 5.18$ $\left(1 \mathrm{H}, \mathrm{s}, \mathrm{CH}_{\mathrm{A}}=\right), 5.21\left(1 \mathrm{H}, \mathrm{d}, J 7.8 \mathrm{~Hz}, \mathrm{CH}_{\mathrm{B}}=\right), 5.68-5.78$ $(1 \mathrm{H}, \mathrm{m},=\mathrm{CH}), 6.38\left(2 \mathrm{H}, \mathrm{d}, J 8.4 \mathrm{~Hz}, 2(6)-\mathrm{H}_{\mathrm{Ar}}\right), 6.91(2 \mathrm{H}$, d, $\left.J 8.0 \mathrm{~Hz}, 3(5)-\mathrm{H}_{\mathrm{Ar}}\right), 7.31(2 \mathrm{H}, \mathrm{dd}, J 4.7,1.1 \mathrm{~Hz}, 3(5)-$ $\left.\mathrm{H}_{\mathrm{Py}}\right), 8.55\left(2 \mathrm{H}, \mathrm{dd}, J 4.6,1.4 \mathrm{~Hz}, 2(6)-\mathrm{H}_{\mathrm{Py}}\right) \cdot{ }^{13} \mathrm{C}-\mathrm{NMR}(100$ MHz) $\delta$ (ppm): 20.3, $42.4(-), 56.4(+), 113.4(2 \mathrm{C},+), 119.0$ $(-), 121.6(2 \mathrm{C},+), 127.0,129.6(2 \mathrm{C},+), 133.6(+), 144.3$, $150.0(2 \mathrm{C},+), 152.9$. GC: $t_{\mathrm{R}} 19.27 \mathrm{~min}$. MS: $\mathrm{m} / z(\%): 238$
$\left(\mathrm{M}^{+}, 4\right), 197$ (100), 91 (8), 65 (4). Anal. calc. for $\mathrm{C}_{16} \mathrm{H}_{16} \mathrm{~N}_{2}$ : C, 80.63; H, 7.61; N, 11.75. Found: C, 80.51; H, 7.49; N, 12.05 .

4-N-(4-Methoxyphenyl)-N-[1-(4-pyridyl)buten-3-yl]amine 8 Yellow viscous oil. Yield: $60 \%$. Molecular formula: $\mathrm{C}_{16} \mathrm{H}_{18} \mathrm{~N}_{2} \mathrm{O}$. Molecular weight: $254.33 \mathrm{~g} \mathrm{~mol}^{-1}$. Eluent: petroleum eter/AcOEt, 20:1. IR ( $\mathrm{KBr}) v_{\max } / \mathrm{cm}^{-1}: 3294$ $\left(v_{\mathrm{NH}}\right), 1597\left(\delta_{\mathrm{NH}}\right) .{ }^{1} \mathrm{H}-\mathrm{NMR}\left(\mathrm{CDCl}_{3}, 400 \mathrm{MHz}\right) \delta(\mathrm{ppm})$ : 2.41-2.61 $\left(2 \mathrm{H}, \mathrm{m},-\mathrm{CH}_{2}\right), 3.68\left(3 \mathrm{H}, \mathrm{s}, \mathrm{OCH}_{3}\right), 4.29(1 \mathrm{H}$, dd, J 8.0, $5.0 \mathrm{~Hz},-\mathrm{CH}), 5.16\left(1 \mathrm{H}, \mathrm{s}, \mathrm{CH}_{\mathrm{B}}=\right), 5.20(1 \mathrm{H}, \mathrm{d}$, $\left.J 6.0 \mathrm{~Hz}, \mathrm{CH}_{\mathrm{A}}=\right), 5.67-5.77(1 \mathrm{H}, \mathrm{m},=\mathrm{CH}), 6.40(2 \mathrm{H}, \mathrm{d}, J$ $\left.8.9 \mathrm{~Hz}, 2(6)-\mathrm{H}_{\mathrm{Ar}}\right), 6.68\left(2 \mathrm{H}, \mathrm{d}, J 8.9 \mathrm{~Hz}, 3(5)-\mathrm{H}_{\mathrm{Ar}}\right), 7.29$ $\left(2 \mathrm{H}, \mathrm{d}, J 6.0 \mathrm{~Hz}, 3(5)-\mathrm{H}_{\mathrm{Py}}\right), 8.53(2 \mathrm{H}, \mathrm{dd}, J 4.5,1.5 \mathrm{~Hz}$, $\left.2(6)-\mathrm{H}_{\mathrm{Py}}\right) .{ }^{13} \mathrm{C}-\mathrm{NMR}(100 \mathrm{MHz}) \delta(\mathrm{ppm}): 42.4,55.6,57.0$, 114.5 (2C), 114.7 (2C), 119.0, 121.6 (2C), 133.6, 140.8, $149.8(2 \mathrm{C}), 152.2,153.1$. GC: $t_{\mathrm{R}} 21.32 \mathrm{~min}$. MS: $\mathrm{m} / \mathrm{z}(\%)$ : $254\left(\mathrm{M}^{+}, 5\right), 213$ (100), 198 (4), 169 (7). Anal. calc. for $\mathrm{C}_{16} \mathrm{H}_{18} \mathrm{~N}_{2} \mathrm{O}: \mathrm{C}, 75.56$; $\mathrm{H}, 7.13$; $\mathrm{N}, 11.01$. Found: C, 75.29; $\mathrm{H}, 7.32 ; \mathrm{N}, 11.12$. 


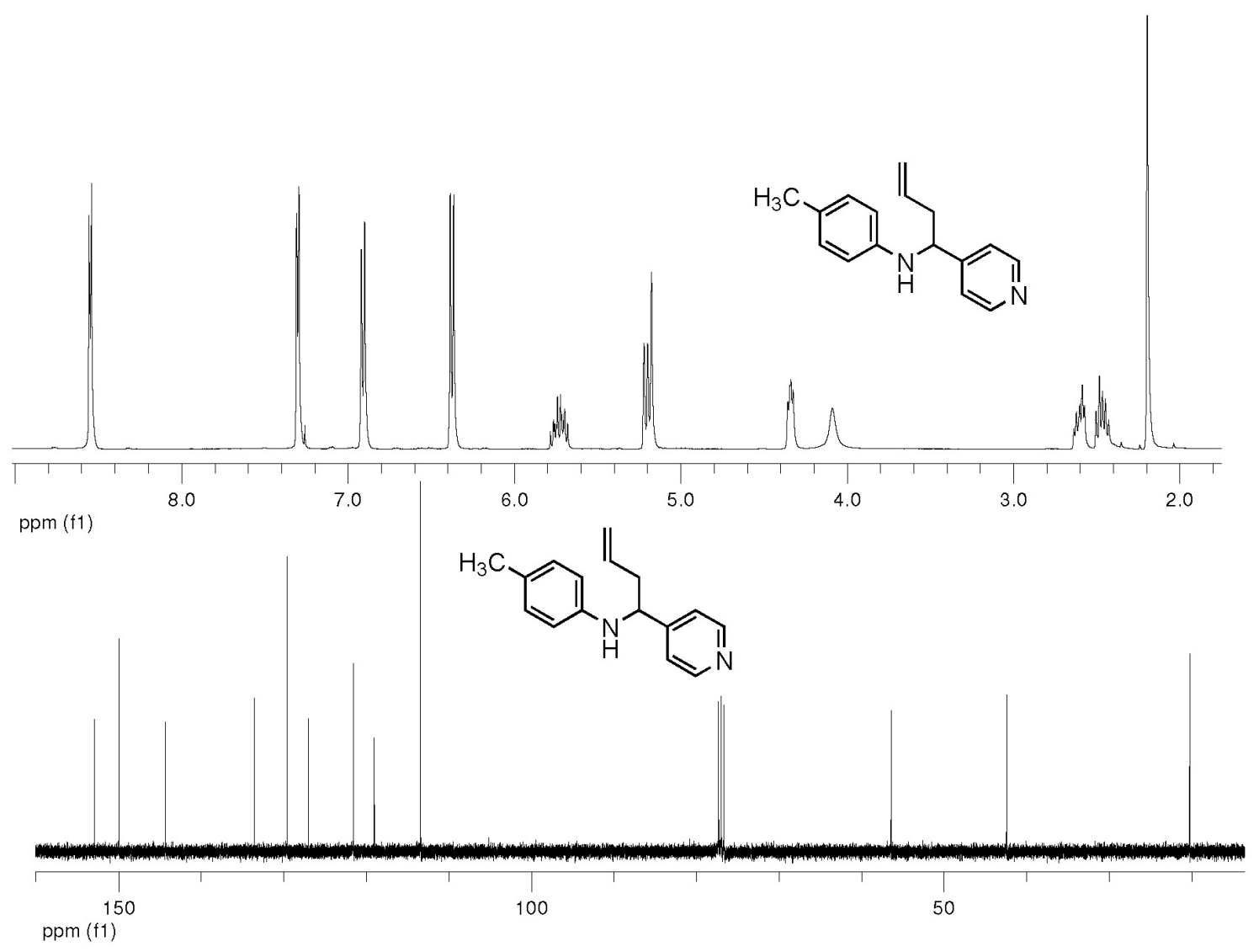

Figure S2. ${ }^{1} \mathrm{H}$ and ${ }^{13} \mathrm{C}$ NMR spectra of 7.

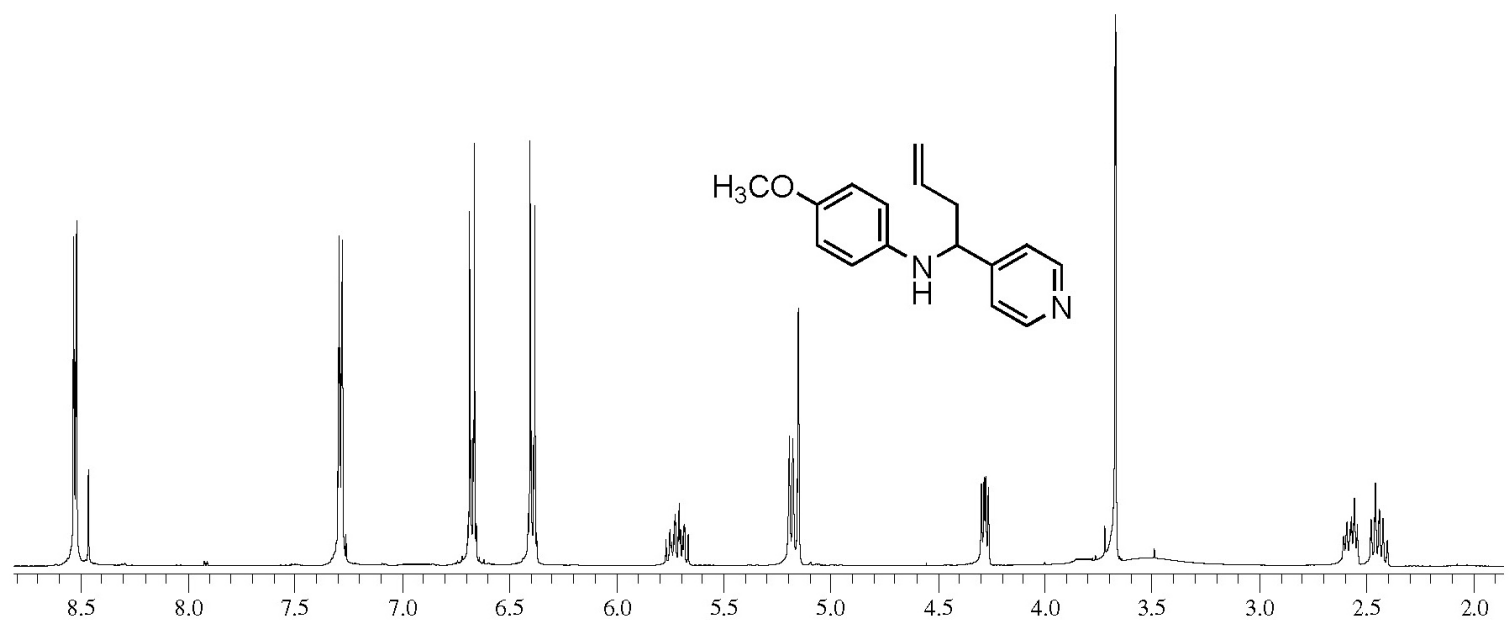

Figure S3. ${ }^{1} \mathrm{H}$ NMR spectrum of $\mathbf{8}$.

4-N-(4-Bromophenyl)-N-[1-(4-pyridyl)buten-3-yl]amine 9 Yellow crystalls. mp 81-83 ${ }^{\circ} \mathrm{C}$. Yield: $53 \%$. Molecular formula: $\mathrm{C}_{15} \mathrm{H}_{15} \mathrm{BrN}_{2}$. Molecular weight: $303.20 \mathrm{~g} \mathrm{~mol}^{-1}$. Eluent: petroleum eter/AcOEt, 10:1. IR (KBr) $v_{\max } / \mathrm{cm}^{-1}$ : $3275\left(v_{\mathrm{NH}}\right), 1594\left(v_{\mathrm{C}=\mathrm{CH}}\right) \mathrm{cm}^{-1} .{ }^{1} \mathrm{H}-\mathrm{NMR}\left(\mathrm{CDCl}_{3}, 300 \mathrm{MHz}\right)$ $\delta$ (ppm): 2.42-2.67 (2H, m, $\left.-\mathrm{CH}_{2}\right), 4.19(1 \mathrm{H}, \mathrm{bs}, \mathrm{N}-\mathrm{H}), 4.34$ $(1 \mathrm{H}, \mathrm{m},-\mathrm{CH}), 5.17-5.23\left(2 \mathrm{H}, \mathrm{m}, \mathrm{CH}_{2}=\right), 5.63-5.78(1 \mathrm{H}$, $\mathrm{m},=\mathrm{CH}), 6.31\left(2 \mathrm{H}, \mathrm{dd}, J 8.8,2.0 \mathrm{~Hz}, 2(6)-\mathrm{H}_{\mathrm{Ar}}\right), 7.16(2 \mathrm{H}$, $\left.\mathrm{dd}, J 8.8,2.0 \mathrm{~Hz}, 3(5)-\mathrm{H}_{\mathrm{Ar}}\right), 7.27(2 \mathrm{H}, \mathrm{dd}, J 3.9,1.7 \mathrm{~Hz}$, $\left.3(5)-\mathrm{H}_{\mathrm{Py}}\right), 8.55\left(2 \mathrm{H}, \mathrm{dd}, J 4.4,1.6 \mathrm{~Hz}, 2(6)-\mathrm{H}_{\mathrm{Py}}\right) .{ }^{13} \mathrm{C}-\mathrm{NMR}$ 
(75 MHz) $\delta(\mathrm{ppm}): 42.3,56.2,109.7,115.0$ (2C), 119.5, 121.5 (2C), 128.1, 131.9 (2C), 133.2, 145.5, 150.0, 150.1. GC: $t_{\mathrm{R}} 22.15 \mathrm{~min}$. MS: $m / z(\%): 302\left(\mathrm{M}^{+}\right.$for $\left.{ }^{79} \mathrm{Br}, 5\right), 261$ $\left[\left(\mathrm{M}_{-} \mathrm{C}_{3} \mathrm{H}_{5}\right)^{+}, 100\right]$. Anal. calc. for $\mathrm{C}_{15} \mathrm{H}_{15} \mathrm{BrN}_{2}: \mathrm{C}, 59.42 ; \mathrm{H}$, 4.99; N, 9.24. Found: C, 59.75; H, 5.21; N, 9.56.

\section{4-N-(3,5-Dimethylphenyl)-N-[1-(4-pyridyl)buten-3-yl] amine 10}

White crystals. Mp $91-92{ }^{\circ} \mathrm{C}$. Yield: $74 \%$. Molecular formula: $\mathrm{C}_{17} \mathrm{H}_{20} \mathrm{~N}_{2}$. Molecular weight: $252.35 \mathrm{~g} \mathrm{~mol}^{-1}$. Eluent: petroleum eter/AcOEt, 10:1. IR (KBr) $v_{\max } / \mathrm{cm}^{-1}$ : $3293\left(v_{\mathrm{NH}}\right), 1603\left(\mathrm{v}_{\mathrm{C}=\mathrm{CH}}\right) .{ }^{1} \mathrm{H}-\mathrm{NMR}\left(\mathrm{CDCl}_{3}, 400 \mathrm{MHz}\right) \delta$ (ppm): $2.15\left(6 \mathrm{H}, \mathrm{s}, 3(5)-\mathrm{CH}_{3}\right), 2.41-2.62\left(2 \mathrm{H}, \mathrm{m},-\mathrm{CH}_{2}\right)$, $4.07(1 \mathrm{H}, \mathrm{bs}, \mathrm{N}-\mathrm{H}), 4.35(1 \mathrm{H}, \mathrm{dd}, J 7.7,5.0 \mathrm{~Hz},-\mathrm{CH})$, 5.20-5.15 (2H, m, $\left.\mathrm{CH}_{2}=\right)$, 5.65-5.76 $(1 \mathrm{H}, \mathrm{m},=\mathrm{CH}), 6.08$ $\left(2 \mathrm{H}, \mathrm{s}, 2(6)-\mathrm{H}_{\mathrm{Ar}}\right), 6.34\left(1 \mathrm{H}, \mathrm{s}, 4-\mathrm{H}_{\mathrm{Ar}}\right), 7.29(2 \mathrm{H}, \mathrm{dd}, J 4.7$, $\left.1.3 \mathrm{~Hz}, 3(5)-\mathrm{H}_{\mathrm{Py}}\right), 8.54\left(2 \mathrm{H}, \mathrm{dd}, J 4.5,1.5 \mathrm{~Hz}, 2(6)-\mathrm{H}_{\mathrm{Py}}\right)$. ${ }^{13} \mathrm{C}-\mathrm{NMR}(100 \mathrm{MHz}) \delta(\mathrm{ppm}): 21.4(2 \mathrm{C}), 42.4,56.2$, 111.3 (2C), 119.0, 119.9, 121.5 (2C), 133.6, 138.8 (2C), 146.8, $150.0(2 \mathrm{C}), 152.9$. GC: $t_{\mathrm{R}} 19.99 \mathrm{~min}$. MS: $\mathrm{m} / z(\%)$ : $252\left(\mathrm{M}^{+}, 3\right), 211(100), 105$ (5), 77 (7). Anal. calc. for $\mathrm{C}_{17} \mathrm{H}_{20} \mathrm{~N}_{2}: \mathrm{C}, 80.91 ; \mathrm{H}, 7.99 ; \mathrm{N}, 11.10$. Found: C, 81.14; $\mathrm{H}, 7.70 ; \mathrm{N}, 11.21$.

General procedure for the preparation of 4-methyl-2-(4pyridyl)-1,2,3,4-tetrahydro-quinolines

$85 \%(\mathrm{v} / \mathrm{v})$ sulfuric acid $(4.0 \mathrm{~mL})$ was added dropwise at $0{ }^{\circ} \mathrm{C}$ to the homoallylamines 6-10 $(2.0 \mathrm{~g})$ in minimal $\mathrm{CH}_{2} \mathrm{Cl}_{2}$ amount, and the resulting mixture was heated at $80-90{ }^{\circ} \mathrm{C}$ for $3 \mathrm{~h}$ while stirring vigorously. The reaction progress was monitored via TLC. At the end of the reaction the mixture
Table S1. Possible fragmentation and principal ions in the MS of homoallylamines 6-10

\begin{tabular}{llc} 
& \\
Compound & $224(3)$ & $183(100)$ \\
\hline $\mathbf{6}$ & $238(4)$ & $197(100)$ \\
$\mathbf{8}$ & $254(5)$ & $213(100)$ \\
$\mathbf{9}$ & $302(5)$ & $261(100)$ \\
$\mathbf{1 0}$ & $252(3)$ & $211(100)$ \\
\hline
\end{tabular}

was cooled down to room temperature and concentrated ammonium hydroxide solution was added to $\mathrm{pH} 10$. Four $25 \mathrm{~mL}$ extractions with dichloromethane were performed. The organic layers were combined, dried $\left(\mathrm{Na}_{2} \mathrm{SO}_{4}\right)$ and concentrated. The oily residue was purified by column chromatography over alumina to give new THQ 11-14 and quinoline sulfonic acid $\mathbf{1 5}$. The synthesis of THQ $\mathbf{1 3}$ was realized using PPA.

\section{4-Methyl-2-(4-pyridyl)-1,2,3,4-tetrahydroquinoline 11}

White crystals. mp $88-90{ }^{\circ} \mathrm{C}$. Yield: $84 \%$. Molecular formula: $\mathrm{C}_{15} \mathrm{H}_{16} \mathrm{~N}_{2}$. Molecular weight: $224.30 \mathrm{~g} \mathrm{~mol}^{-1}$. Eluent: petroleum eter/AcOEt, 5:1. IR (KBr) $v_{\max } / \mathrm{cm}^{-1}$ : $3266\left(v_{\mathrm{NH}}\right) .{ }^{1} \mathrm{H}-\mathrm{NMR}\left(\mathrm{CDCl}_{3}, 400 \mathrm{MHz}\right) \delta(\mathrm{ppm})$ : cis Isomer: $1.34\left(3 \mathrm{H}, \mathrm{d}, J 6.8 \mathrm{~Hz}, 4-\mathrm{CH}_{3}\right), 1.70(1 \mathrm{H}, \mathrm{c}, J$ $12.7 \mathrm{~Hz}, 3-\mathrm{Ha}), 2.11$ (1H, ddd, $J 12.9,4.3,3.0 \mathrm{~Hz}, 3-\mathrm{He})$, $3.13(1 \mathrm{H}, \mathrm{sp}, J 6.0 \mathrm{~Hz}, 4-\mathrm{H}), 4.00(1 \mathrm{H}, \mathrm{s}, \mathrm{NH}), 4.47(1 \mathrm{H}$,

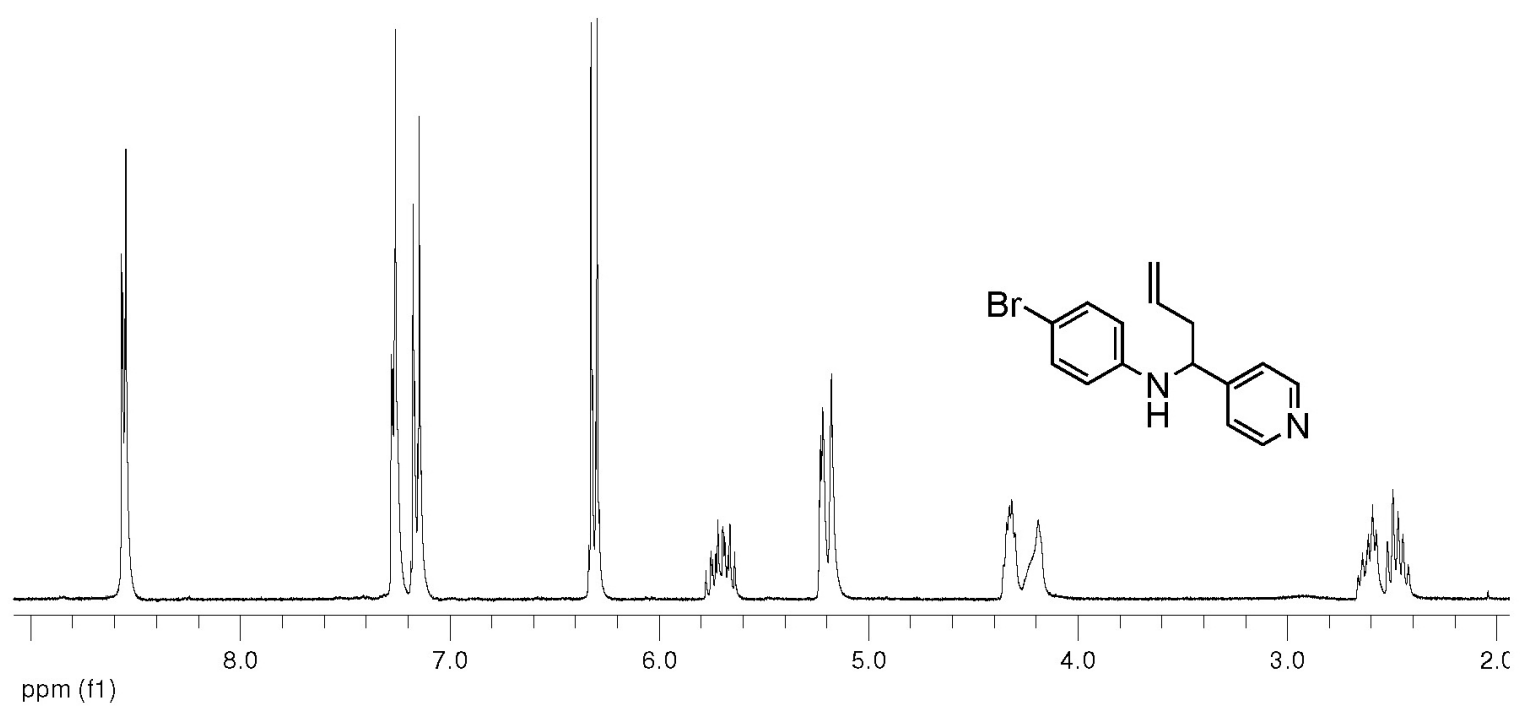

Figure S4. ${ }^{1} \mathrm{H}$ NMR spectrum of 9. 


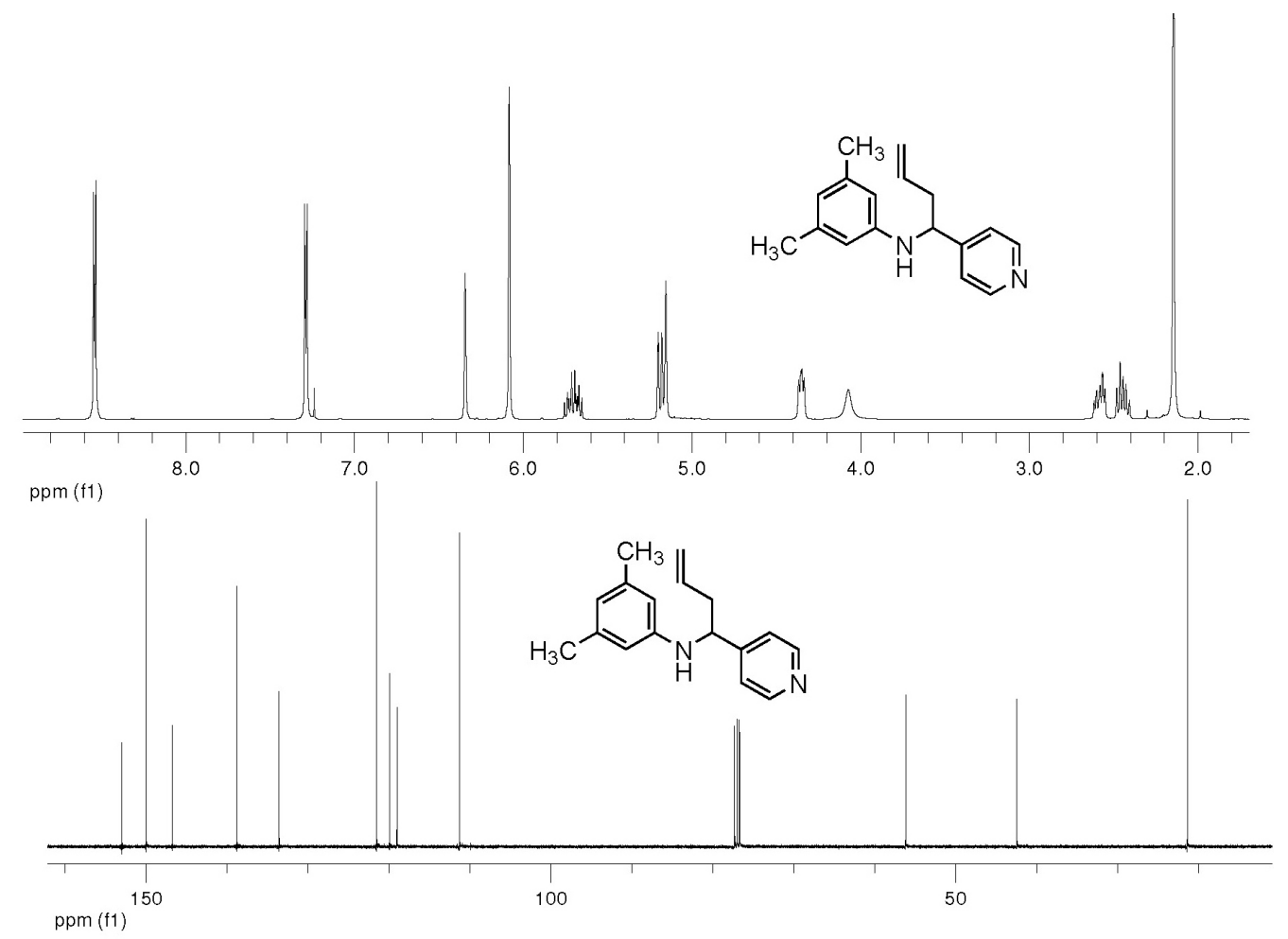

Figure S5. ${ }^{1} \mathrm{H}$ and ${ }^{13} \mathrm{C}$ NMR spectra of $\mathbf{1 0}$.
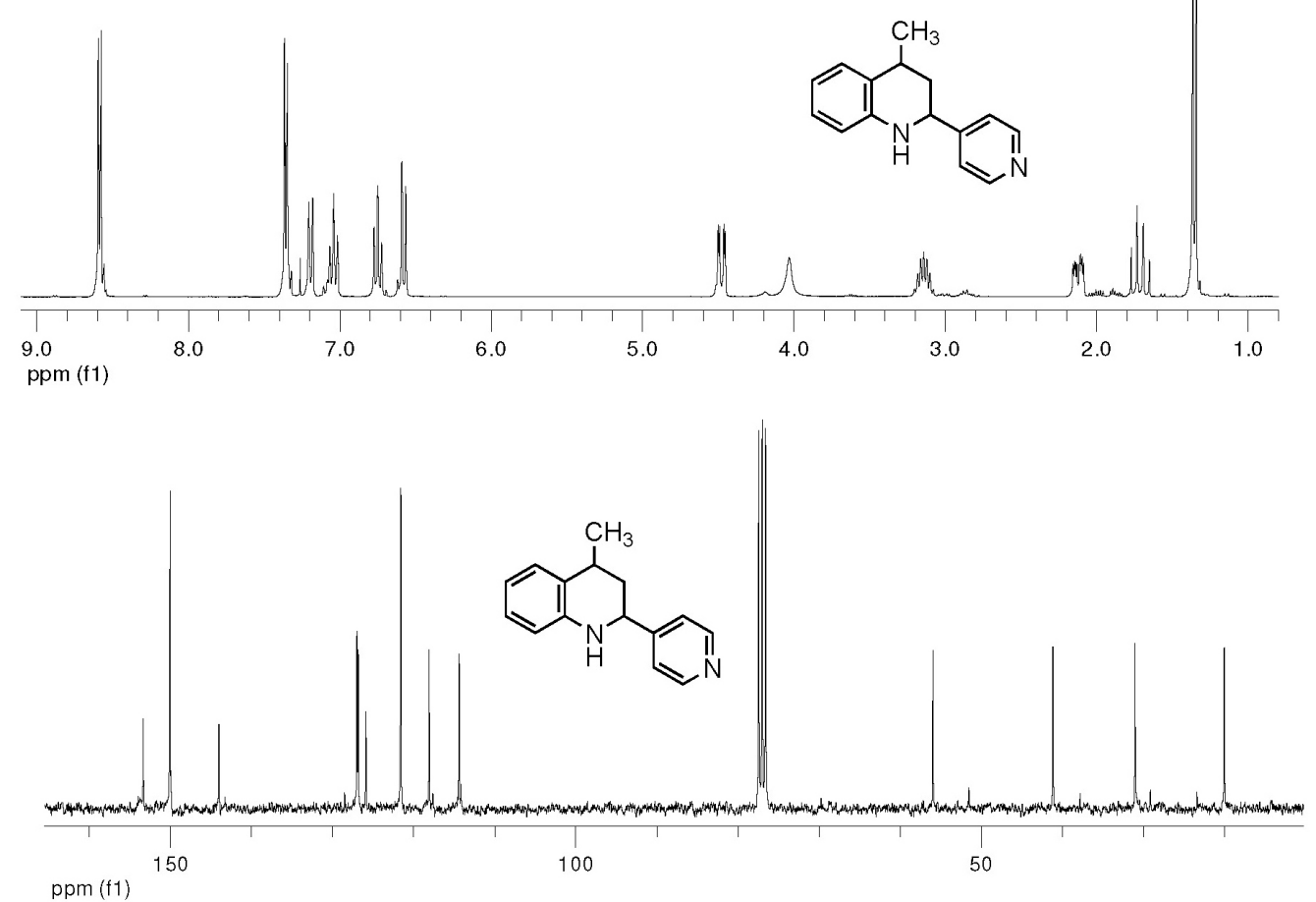

Figure S6. ${ }^{1} \mathrm{H}$ and ${ }^{13} \mathrm{C}$ NMR spectra of $\mathbf{1 1}$. 
dd, $J 11.3,2.8 \mathrm{~Hz}, 2-\mathrm{H}), 6.56$ (1H, dd, J 7.9, $0.9 \mathrm{~Hz}, 8-\mathrm{H})$, $6.74(1 \mathrm{H}, \mathrm{td}, J 7.4,0.9 \mathrm{~Hz}, 6-\mathrm{H}), 7.03(1 \mathrm{H}, \mathrm{t}, J 7.6 \mathrm{~Hz}, 7-\mathrm{H})$, $7.18(1 \mathrm{H}, \mathrm{d}, J 7.7 \mathrm{~Hz}, 5-\mathrm{H}), 7.35$ (2H, dd, J 4.7, $1.3 \mathrm{~Hz}$, $\left.3(5)-\mathrm{H}_{\mathrm{Py}}\right), 8.58\left(2 \mathrm{H}, \mathrm{dd}, J 4.5,1.5 \mathrm{~Hz}, 2(6)-\mathrm{H}_{\mathrm{Py}}\right) \cdot{ }^{13} \mathrm{C}-\mathrm{NMR}$ (100 MHz) $\delta$ (ppm): 20.1, 31.1, 41.2, 56.0, 114.4, 118.2, 121.6 (2C), 126.0, 126.9, 127.1, 144.1, 150.2 (2C), 153.4. GC: $t_{\mathrm{R}} 20.06 \mathrm{~min}$. MS: $m / z(\%): 224\left(\mathrm{M}^{+}, 9\right), 132(100)$, 117 (28), 93 (29), 77 (5). $t_{\mathrm{R}} 20.29$ min. $224\left(\mathrm{M}^{+}, 91\right), 209$ (46), 146 (100), 130 (24), 117 (15), 104 (7), 91 (11), 77 (14), 51 (8). Anal. calc. for $\mathrm{C}_{15} \mathrm{H}_{16} \mathrm{~N}_{2}$ : C, 80.32; H, 7.19; N, 12.49. Found: C, 80.34; H, 7.23; N, 12.51 .

\section{4,6-Dimethyl-2-(4-pyridyl)-1,2,3,4-tetrahydroquinoline 12}

White crystals. mp 138-139 ${ }^{\circ} \mathrm{C}$. Yield: $72 \%$. Molecular formula: $\mathrm{C}_{16} \mathrm{H}_{18} \mathrm{~N}_{2}$. Molecular weight: $238.33 \mathrm{~g} \mathrm{~mol}^{-1}$. Eluent: petroleum eter/AcOEt, 5:1. IR $(\mathrm{KBr}) \mathrm{v}_{\max } / \mathrm{cm}^{-1}$ : $3273\left(\mathrm{v}_{\mathrm{NH}}\right) \mathrm{cm}^{-1} .{ }^{1} \mathrm{H}-\mathrm{NMR}\left(\mathrm{CDCl}_{3}, 400 \mathrm{MHz}\right) \delta(\mathrm{ppm})$ : cis Isomer: $1.34\left(3 \mathrm{H}, \mathrm{d}, J 6.8 \mathrm{~Hz}, 4-\mathrm{CH}_{3}\right), 1.69(1 \mathrm{H}, \mathrm{c}, J 11.6$ Hz, 3-Ha), 2.10 (1H, ddd, J 12.9, 5.3, 2.1 Hz, 3-He), 2.26 $\left(3 \mathrm{H}, \mathrm{s}, 6-\mathrm{CH}_{3}\right), 3.12(1 \mathrm{H}, \mathrm{sp}, J 6.6 \mathrm{~Hz}, 4-\mathrm{H}), 3.86$ (1H, bs, $\mathrm{NH}), 4.43(1 \mathrm{H}, \mathrm{dd}, J 11.3,2.6 \mathrm{~Hz}, 2-\mathrm{H}), 6.50(1 \mathrm{H}, \mathrm{d}, J 8.0$ $\mathrm{Hz}, 8-\mathrm{H}), 6.86$ (1H, d, J 8.0 Hz, 7-H), 7.00 (1H, s, 5-H), 7.35 $\left(2 \mathrm{H}, \mathrm{dd}, J 4.5,1.4 \mathrm{~Hz}, 3(5)-\mathrm{H}_{\mathrm{Py}}\right), 8.58(2 \mathrm{H}, \mathrm{dd}, J 4.4,1.6 \mathrm{~Hz}$,
2(6)- $\left.\mathrm{H}_{\mathrm{Py}}\right) \cdot{ }^{13} \mathrm{C}-\mathrm{NMR}(100 \mathrm{MHz}) \delta(\mathrm{ppm}): 20.2,20.6,31.1$, 41.4, 56.1, 114.6, 121.6 (2C), 126.0, 127.3, 127.5, 127.6, 141.7, 150.1 (2C), 153.5. GC: $t_{\mathrm{R}} 20.78 \mathrm{~min}$. MS: $m / z(\%)$ : $238\left(\mathrm{M}^{+}, 10\right), 146(100), 131(26), 93(25) . t_{\mathrm{R}} 21.84 \mathrm{~min} .238$ ( $\left.\mathrm{M}^{+}, 100\right), 223$ (44), 160 (83), 144 (20), 130 (12), 115 (8), 91 (8), 51 (6). Anal. calc. for $\mathrm{C}_{16} \mathrm{H}_{16} \mathrm{~N}_{2}$ : C, 80.63; H, 7.61; N, 11.75. Found: C, 80.33; H, 7.57; N, 12.02.

4-Methyl-6-methoxy-2-(4-pyridyl)-1,2,3,4-tetrahydroquinoline 13

Yellow crystals. mp $113-115^{\circ} \mathrm{C}$. Yield: $54 \%$. Molecular formula: $\mathrm{C}_{16} \mathrm{H}_{18} \mathrm{~N}_{2} \mathrm{O}$. Molecular weight: $254.33 \mathrm{~g} \mathrm{~mol}^{-1}$. Eluent: petroleum eter/AcOEt, 1:1. IR (KBr) $v_{\max } / \mathrm{cm}^{-1}$ : $3267\left(v_{\mathrm{NH}}\right)$. ${ }^{1} \mathrm{H}-\mathrm{NMR}\left(\mathrm{CDCl}_{3}, 300 \mathrm{MHz}\right) \delta(\mathrm{ppm})$ : cis Isomer: $1.33\left(3 \mathrm{H}, \mathrm{d}, J 6.8 \mathrm{~Hz}, 4-\mathrm{CH}_{3}\right), 1.69(1 \mathrm{H}, \mathrm{c}, J$ $11.6 \mathrm{~Hz}, 3-\mathrm{Ha}), 2.11$ (1H, ddd, J 13.0, 5.5, $2.7 \mathrm{~Hz}, 3-\mathrm{He})$, $3.13(1 \mathrm{H}, \mathrm{sp}, J 6.3 \mathrm{~Hz}, 4-\mathrm{H}), 3.76(3 \mathrm{H}, \mathrm{s} \mathrm{OCH}), 4.40(1 \mathrm{H}$, dd, $J 11.2,2.3 \mathrm{~Hz}, 2-\mathrm{H}), 6.56$ (1H, d, J 8.6 Hz, 8-H), 6.65 (1H, dd, J 8.6, $2.8 \mathrm{~Hz}, 7-\mathrm{H}), 6.79$ (1H, d, J $2.7 \mathrm{~Hz}, 5-\mathrm{H})$, $7.36\left(2 \mathrm{H}, \mathrm{dd}, J 4.6,1.6 \mathrm{~Hz}, 3(5)-\mathrm{H}_{\mathrm{Py}}\right), 8.58(2 \mathrm{H}, \mathrm{dd}, J 4.6$, $\left.1.6 \mathrm{~Hz}, 2(6)-\mathrm{H}_{\mathrm{Py}}\right) \cdot{ }^{13} \mathrm{C}-\mathrm{NMR}(75 \mathrm{MHz}) \delta(\mathrm{ppm}): 20.3,31.3$, 41.3, 55.8, 56.2, 112.6, 113.1, 115.4, 121.7 (2C), 127.4, $138.2,150.0(2 \mathrm{C}), 152.5,153.5$. GC: $t_{\mathrm{R}} 22.74 \mathrm{~min} . \mathrm{MS}$ :
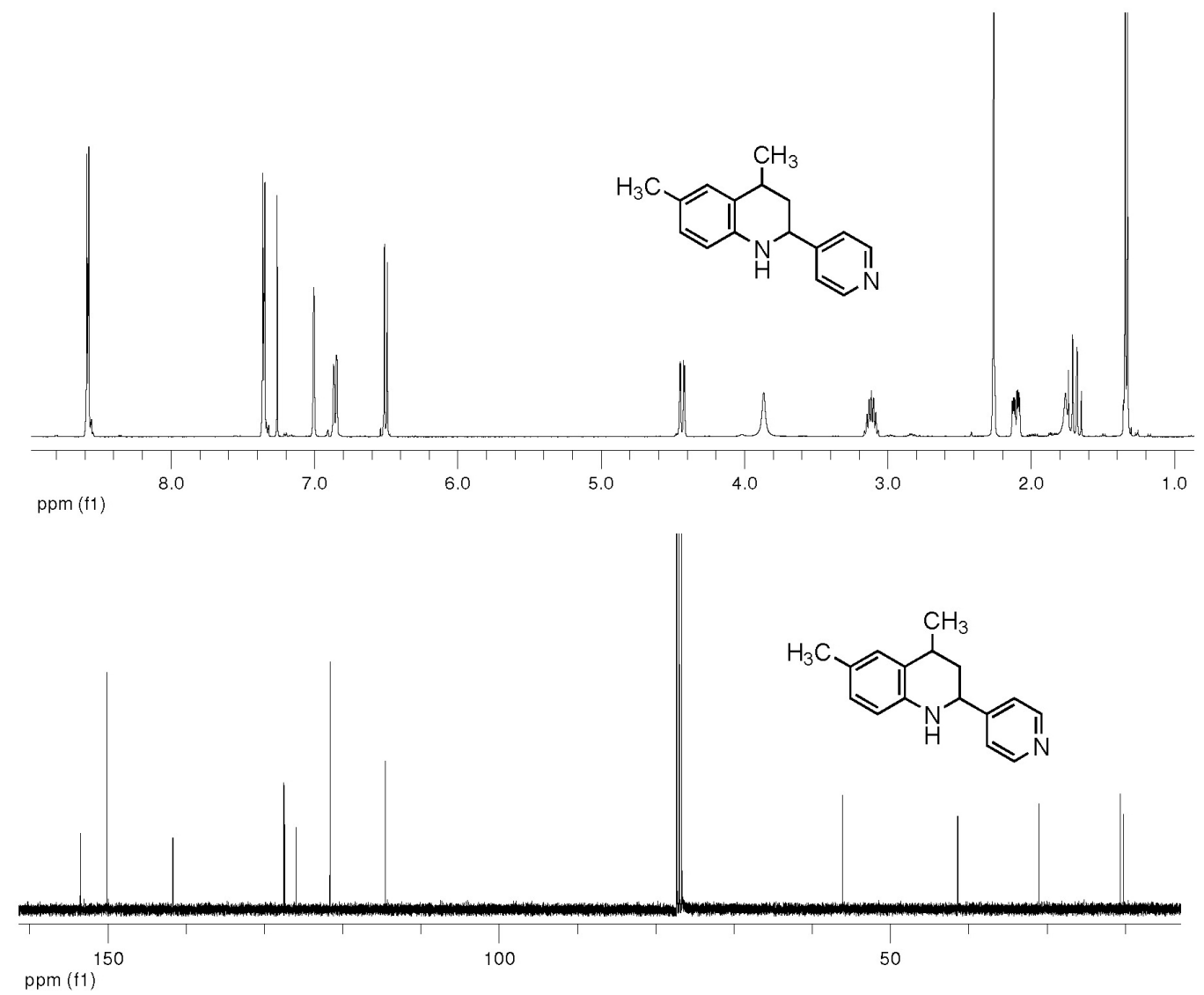

Figure S7. ${ }^{1} \mathrm{H}$ and ${ }^{13} \mathrm{C}$ NMR spectra of $\mathbf{1 2}$. 

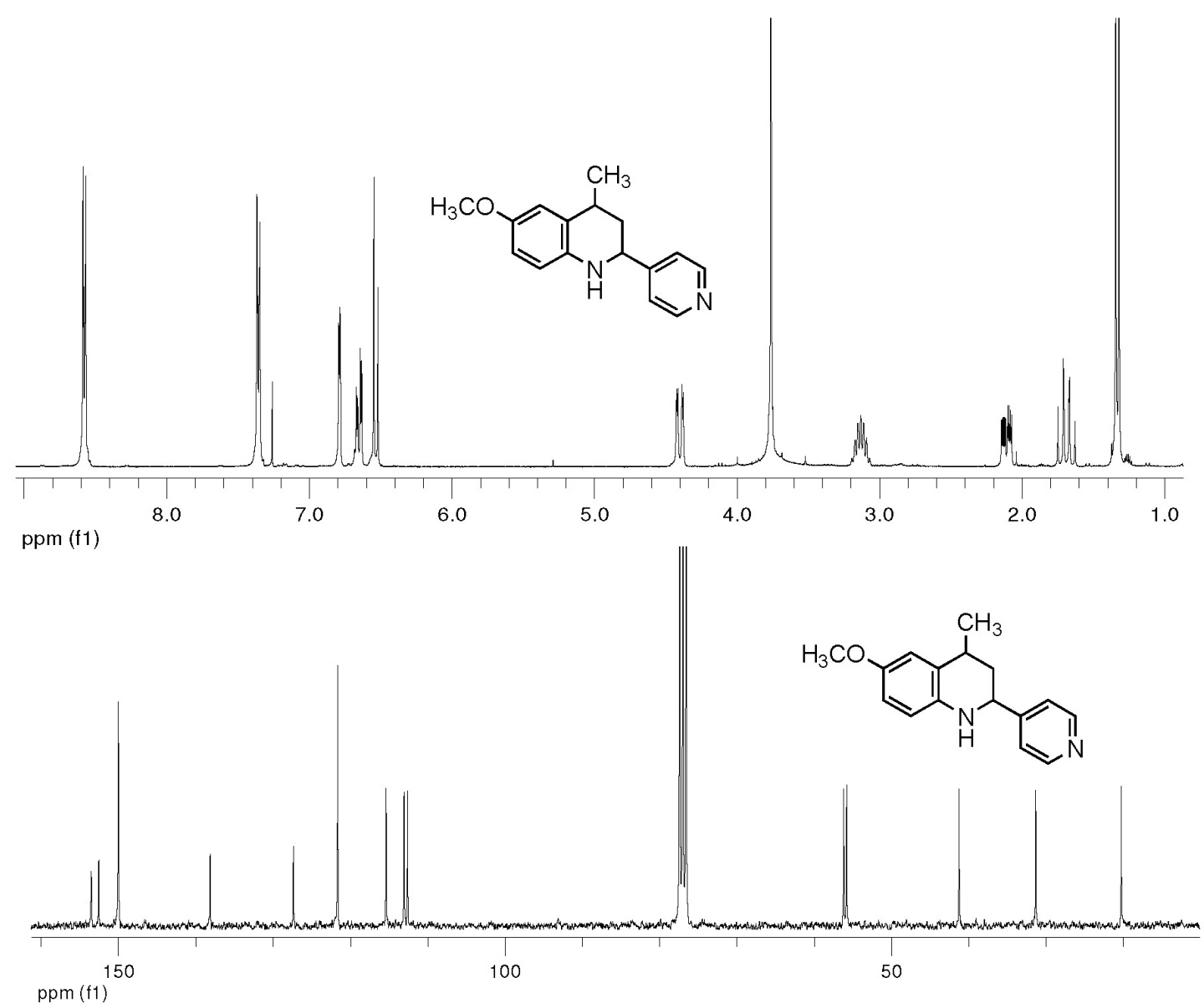

Figure S8. ${ }^{1} \mathrm{H}$ and ${ }^{13} \mathrm{C}$ NMR spectra of $\mathbf{1 3}$.

m/z (\%): $254\left(\mathrm{M}^{+}, 100\right), 239$ (60), 176 (61), 93 (5). Anal. calc. for $\mathrm{C}_{16} \mathrm{H}_{18} \mathrm{~N}_{2} \mathrm{O}$ : C, 75.56; H, 7.13; N, 11.01. Found: C, 75.44; H, 7.08; N, 11.15.

6-Bromo-4-methyl-(4-pyridyl)-1,2,3,4-tetrahydroquinoline 14

Yellow crystals. mp $104-106^{\circ} \mathrm{C}$. Yield: $68 \%$. Molecular formula: $\mathrm{C}_{15} \mathrm{H}_{15} \mathrm{BrN}_{2}$. Molecular weight: $303.20 \mathrm{~g} \mathrm{~mol}^{-1}$. Eluent: AcOEt. IR (KBr) $v_{\max } / \mathrm{cm}^{-1}: 3256\left(\mathrm{v}_{\mathrm{NH}}\right) .{ }^{1} \mathrm{H}-\mathrm{NMR}$ $\left(\mathrm{CDCl}_{3}, 300 \mathrm{MHz}\right) \delta$ (ppm): cis Isomer: $1.33(3 \mathrm{H}, \mathrm{d}, J 6.8$ $\left.\mathrm{Hz}, 4-\mathrm{CH}_{3}\right), 1.67$ (1H, c, J 11.5 Hz, 3-Ha), 2.09 (1H, bt, $J$ $13.1 \mathrm{~Hz}, 3-\mathrm{He}), 3.10$ (1H, sp, J $6.4 \mathrm{~Hz}, 4-\mathrm{H}), 4.05$ (1H, bs, N-H), 4.46 (1H, dd, J 11.2, $2.9 \mathrm{~Hz}, 2-\mathrm{H}), 6.45$ (1H, d, $J$ $8.5 \mathrm{~Hz}, 8-\mathrm{H}), 7.11$ (1H, dd, J 8.5, $2.3 \mathrm{~Hz}, 7-\mathrm{H}), 7.27(1 \mathrm{H}$, d, J 2.2 Hz, 5-H), $7.34\left(2 \mathrm{H}, \mathrm{dd}, J 4.4,1.6 \mathrm{~Hz}, 3(5)-\mathrm{H}_{\mathrm{Py}}\right)$, 8.59 (2H, dd, J 4.5, $\left.1.6 \mathrm{~Hz}, 2(6)-\mathrm{H}_{\mathrm{Py}}\right) .{ }^{13} \mathrm{C}-\mathrm{NMR}(75 \mathrm{MHz})$ $\delta$ (ppm): 19.8, 31.0, 40.6, 55.9, 109.8, 115.9, 121.5 (2C), 128.0, 129.6, 129.7, 143.1, $150.1(2 \mathrm{C}), 152.9$. GC: $t_{\mathrm{R}} 23.30$ min. MS: $m / z$ (\%): $302\left(\mathrm{M}^{+}\right.$for $\left.{ }^{79} \mathrm{Br}, 100\right), 287$ (19), 224 (80), 208 (48), 145 (39), 130 (87). $t_{\mathrm{R}} 24.05 \mathrm{~min} .302\left(\mathrm{M}^{+}\right.$ for $\left.{ }^{79} \mathrm{Br}, 100\right), 287$ (13), 224 (74), 208 (47), 145 (24), 130 (68). Anal. calc. for $\mathrm{C}_{15} \mathrm{H}_{15} \mathrm{BrN}_{2}$ : C, 59.42; H, 4.99; N, 9.24. Found: C, 59.23; H, 5.16; N, 9.33.

Acid 4,5,7-trimethyl-2-(4-pyridyl)quinoline-8-sulfonic 15 Green crystals. mp 239-240 ${ }^{\circ} \mathrm{C}$. Yield: $56 \%$. Molecular formula: $\mathrm{C}_{17} \mathrm{H}_{16} \mathrm{~N}_{2} \mathrm{O}_{3} \mathrm{~S}$. Molecular weight: $328.39 \mathrm{~g} \mathrm{~mol}^{-1}$. Eluent: AcOEt/MeOH, 20:1. IR (KBr) $v_{\max } / \mathrm{cm}^{-1}: 1265$, $1180\left(\mathrm{v}_{\mathrm{S}=\mathrm{O}}\right), 710\left(\mathrm{v}_{\mathrm{S}-\mathrm{O}}\right) \cdot{ }^{1} \mathrm{H}-\mathrm{NMR}(\mathrm{DMSO}-\mathrm{d} 6,400 \mathrm{MHz})$ $\delta$ (ppm): $2.39\left(3 \mathrm{H}, \mathrm{s}, 5-\mathrm{CH}_{3}\right), 2.75\left(3 \mathrm{H}, \mathrm{s}, 4-\mathrm{CH}_{3}\right), 2.83$ (3H, s, 7- $\left.\mathrm{CH}_{3}\right), 7.17(1 \mathrm{H}, \mathrm{s}, 5-\mathrm{H}), 7.59(1 \mathrm{H}, \mathrm{s}, 3-\mathrm{H}), 7.93$ $\left(2 \mathrm{H}, \mathrm{dd}, J 5.2,1.2 \mathrm{~Hz}, 3(5)-\mathrm{H}_{\mathrm{Py}}\right), 8.69$ (2H, dd, J 6.0, 1.0 $\left.\mathrm{Hz}, 2(6)-\mathrm{H}_{\mathrm{Py}}\right), 9.17$ (1H, bs, O-H). ${ }^{13} \mathrm{C}-\mathrm{NMR}(100 \mathrm{MHz})$ $\delta$ (ppm): 15.4, 20.5, 24.8, 123.8 (2C), 126.9, 127.5, 130.3, 132.3, 134.0, 135.3, 144.3, 145.7, 146.1, 147.5, 149.3 (2C). GC: $t_{\mathrm{R}} 26.06 \mathrm{~min}$. MS: $m / z(\%): 328\left(\mathrm{M}^{+}, 100\right), 235$ (52), 221 (12), 158 (15), 128 (7), 115 (13). Anal. calc. for $\mathrm{C}_{17} \mathrm{H}_{16} \mathrm{~N}_{2} \mathrm{O}_{3} \mathrm{~S}: \mathrm{C}, 62.18 ; \mathrm{H}, 4.91 ; \mathrm{N}, 8.53$. Found: $\mathrm{C}, 62.25$; $\mathrm{H}, 4.77$; N, 8.37. 

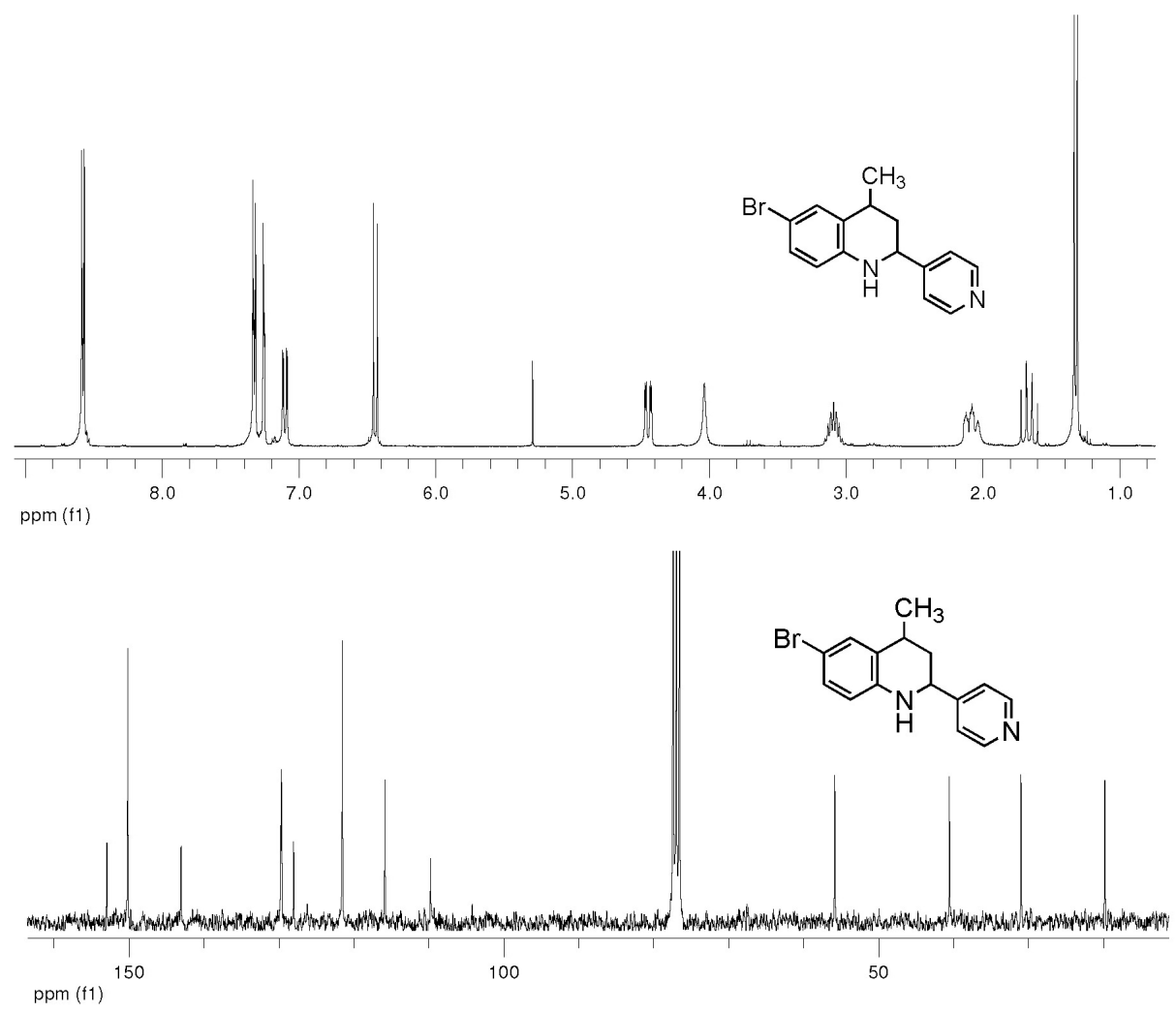

Figure S9. ${ }^{1} \mathrm{H}$ and ${ }^{13} \mathrm{C}$ NMR spectra of $\mathbf{1 4}$.

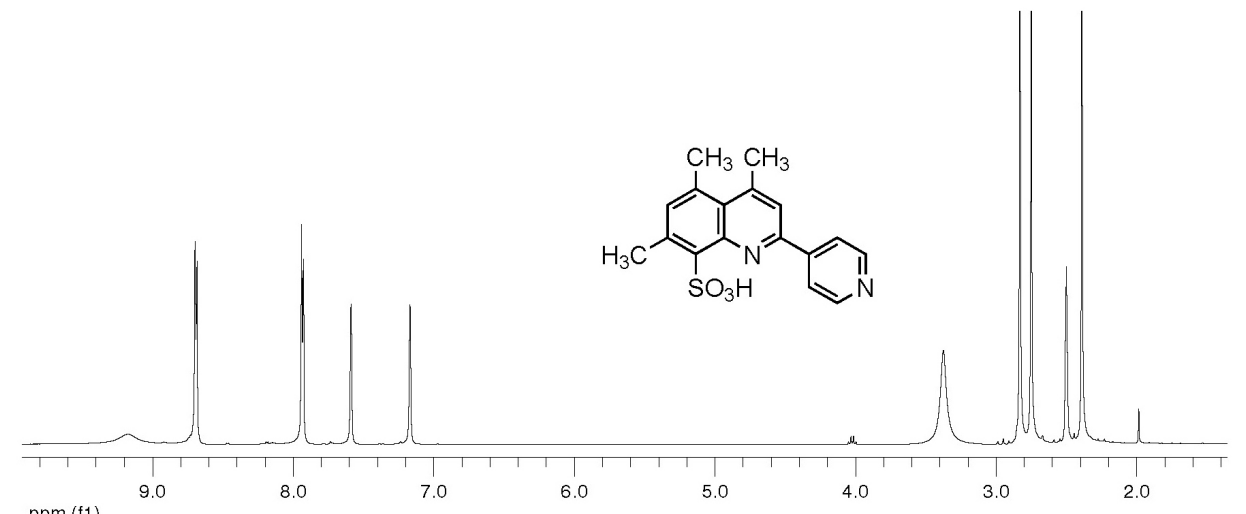

ppm (f1)
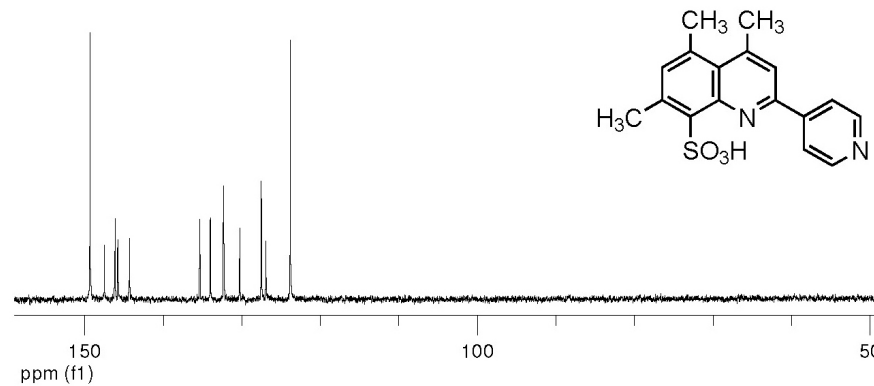

$$
\text { ppm (f1) }
$$

Figure S10. ${ }^{1} \mathrm{H}$ and ${ }^{13} \mathrm{C}$ NMR spectra of $\mathbf{1 5}$. 